\title{
The Impact of the Financial Crisis on Nonfinancial Firms: The Case of Brazilian Corporations and the "Double Circularity" Problem in Transnational Securities Litigation
}

\author{
Érica Gorga*
}

This Article discusses the impact of the international financial crisis on Brazilian capital markets. While the banking industry was not severely affected, leading nonfinancial corporations experienced severe financial turmoil. Two Brazilian corporations cross-listed in the United States - Sadia S.A. and Aracruz Celulose S.A. - suffered billion-dollar losses when the Brazilian real unexpectedly plummeted in relation to the dollar. Despite earlier disclosure that these companies had engaged only in pure hedging activity, these great losses were found to be the result of their highly speculative trading in currency

* Associate Research Scholar in Law at Yale Law School and the John R. Raben/ Sullivan \& Cromwell Executive Director for the Yale Law School Center for the Study of Corporate Law. Professor of Law, Fundação Getulio Vargas São Paulo Law School (FGV DIREITO SP).E-mails: erica.gorga@yale.edu; erica. gorga@fgv.br. I am thankful to Ilya Beylin, Yael Braudo, Hannah L. Buxbaum, George Conwag III, Aaron Dhir, Luca Enriques, Noam Gilon, Assaf Hamdani, Karen Mijelshon, John Morley, Marian Moszoro, Shai Oksenberg, Roberta Romano, Etia Rottman-Frand, Bruno Salama, Natalya Shnitser, Hila Spies, Marco Ventoruzzo, Barak Yarkoni, and to participants of the international conference on Financial Regulation and Comparative Corporate Governance, held at Tel Aviv University Buchmann Faculty of Law in January of 2014, of the Yale Law School Center for the Study of Corporate Law Occasional Lectures in February of 2014, and of the Fall 2014 Law \& Finance Workshop and Lecture Series of the Swiss Federal Institute of Technology, ETH Zurich, for comments received on an earlier version. I also would like to thank the research support of Matheus Lopes Ferreira de Sousa and the editorial assistance of Laura Femino. I am grateful to FAPESP (São Paulo Research Foundation) and to the Yale Law School Center for the Study of Corporate Law for financial support of this research. 
derivatives. Consequently, several private lawsuits were filed both in the United States and in Brazil.

This Article takes a novel approach to the transnational securities litigation debate by examining the particular consequences of private litigation in a developed and in an emerging country. It compares the types of lawsuits filed and their final outcomes. Despite substantially similar alleged wrongdoing, the outcomes for securities holders in each jurisdiction contrast strikingly. Only U.S. investors of both companies were able to obtain substantial financial recoveries; Brazilian investors obtained none. This Article examines the reasons behind these discrepant results and the consequent economic distributional effects on global securities markets after the U.S. Supreme Court decision in Morrison.

The Article argues that Morrison aggravates such (i) shareholder cross-border non pro rata compensation and (ii) transfers of company value from foreign to U.S. investors. It identifies a set of costs borne by foreign investors, and so far neglected by scholars, as a consequence of the current status of U.S. and international securities law regimes. These costs are the result not only of the typical "circularity problem" in securities litigation, but also of a "double circularity problem" as they fall on foreign shareholders who also suffered equivalent damages to those experienced by the U.S. class being compensated. The Article then discusses potential policy reforms for fixing transnational securities litigation.

\section{INTRODUCTION}

The most recent international financial crisis has generated a vast academic literature. Scholars have extensively analyzed the causes of the crisis and its effects on financial markets and regulation. ${ }^{1}$ Researchers have devoted

1 See, e.g., Richard A. Posner, A Failure of Capitalism: The Crisis of '08 and the Descent into Depression (2009); Robert J. Shiller, Subprime Solution: How Today's Global Financial Crisis Happened and What to Do About It (2008); Robert J. Shiller \& Randall Kroszner, Reforming US Financial Markets: Reflections Before and Beyond Dodd-Frank (2011); Roberta Romano, Regulating in the Dark, in Regulatory Breakdown: The Crisis of Confidence In U.S. Regulation 86 (Cary Coglianese ed., 2012); Roberta Romano, For Diversity in the International Regulation of Financial Institutions: Critiquing and Recalibrating the Basel Architecture (Yale Law \& Econ., Working Paper No. 452, 2013), available at http://ssrn.com/abstract=2127749. 
special attention to how the corporate governance practices of financial institutions influenced the crisis, ${ }^{2}$ and to corporate governance reforms in post-crisis regulation. ${ }^{3}$ However, much less attention has been paid to how the financial crisis affected the performance of nonfinancial firms and their corporate governance practices around the world. ${ }^{4}$

This Article contributes to filling this gap. It analyzes how the financial crisis affected large nonfinancial firms in Brazil. This is a valuable inquiry because of the peculiarities of the Brazilian financial and capital markets and the distinctive consequences brought by the crisis. First, the Brazilian banking industry - when compared to that of other countries - was not severely affected by the international financial crisis, largely as a result of its conservative financial practices. ${ }^{5}$ Second, the international financial crisis burst in 2008, immediately after the booming capital market years of Novo Mercado in 2006 and $2007 .{ }^{6}$ Because it generated a strong shock for capital

2 See, e.g., David H. Erkens, Mingyi Hung \& Pedro Matos, Corporate Governance in the 2007-2008 Financial Crisis: Evidence from Financial Institutions Worldwide, 18 J. CORP. Fin. 389 (2012).

3 See, e.g., Stephen M. Bainbridge, Dodd-Frank: Quack Federal Corporate Governance Round II, 95 MinN. L. Rev. 1779 (2011); Stephen M. Bainbridge, The Corporate Governance Provisions of Dodd-Frank (UCLA School of Law, Law-Econ. Working Paper No. 10-14, 2010), available at http://ssrn.com/ abstract $=1698898$.

4 See, e.g., Kartick Gupta, Chandrasekhar Krishnamurti \& Alireza Tourani-Rad, Is Corporate Governance Relevant During the Financial Crisis?, 23 J. INT'L Fin. MKt. Institutions \& Money 85 (2013) (finding a lack of impact of internal corporate governance quality on the performance of a large sample of nonfinancial publicly held companies during the financial crisis). In contrast, this Article will explore case studies in which flaws of internal corporate governance quality during the crisis produced strongly negative performances.

5 See generally Enrique R. Carrasco \& Sean Williams, Emerging Economies After the Global Financial Crisis: The Case of Brazil, 33 Nw. J. InT'L L. \& Bus. 81 (2012) (arguing that in general "[e]merging economies have rebounded relatively quickly from the 2008 global financial crisis"). A few medium Brazilian banks suffered from liquidity problems, and were acquired by larger banks.

6 Novo Mercado is a special listing segment of the largest Brazilian stock exchange, BM\&FBovespa. In 2000, BM\&FBovespa created three listing segments - Novo Mercado, Level 2, and Level 1 - to which firms can voluntarily migrate. To list in these segments, firms have to comply with stricter standards of corporate governance than those determined by Brazilian corporate law. Novo Mercado adopts the most stringent rules, followed by Level 2 and Level 1. The previously existing traditional market requires no additional compliance beyond state law. The success of these new listing markets has attracted a lot of media and academic 
markets around the world, there was a lot of speculation as to whether Novo Mercado would pass it unscathed. To be sure, the activity of initial public offerings (IPOs) in the Brazilian market was affected by the crisis. IPO activity significantly decreased in 2008 and 2009, recovered slightly in 2010 and 2011, but diminished again in 2012 and 2013. ${ }^{7}$ While there is a paucity of work on the impact of the crisis on Brazilian capital markets, a recent study analyzing 2013 data from corporate ownership structures shows that the greater ownership dispersion achieved by Novo Mercado firms has largely remained stable at pre-crisis numbers. ${ }^{8}$

The direct impact of the international crisis on Brazil therefore seemed less pronounced than the acute financial woes experienced in other markets and aggravated by the European crisis. ${ }^{9}$ Yet, by looking at aggregate financial

attention. See, e.g., Ronald J. Gilson, Henry Hansmann \& Mariana Pargendler, Regulatory Dualism as a Development Strategy: Corporate Reform in Brazil, the United States, and the European Union, 63 StAn. L. REv. 475 (2013); Érica Gorga, Changing the Paradigm of Stock Ownership from Concentrated Towards Dispersed Ownership? Evidence from Brazil and Consequences for Emerging Countries, 29 Nw. J. InT'L L. \& Bus. 439 (2009); Bernard S. Black, Antonio Gledson de Carvalho \& Joelson Oliveira Sampaio, The Evolution of Corporate Governance in Brazil (Nw. Law \& Econ. Working Paper No. 12-22, 2012), available at $\mathrm{http}: / / \mathrm{ssrn} . \mathrm{com} / \mathrm{abstract}=2181039$.

7 See data from Comissão de Valores Mobiliários (CVM), the Brazilian Securities and Exchange Commission. This decrease in IPO numbers cannot be exclusively attributed to the financial crisis, as it can also be explained by other shortcomings of Brazil's economy and capital markets.

8 Because the crisis caused securities prices to significantly drop, one could hypothesize that former controlling shareholders - who sold shares for high prices at IPOs or secondary offerings - and other investors could cheaply acquire shares at a discount in the secondary market and gain corporate control in order to extract private benefits. Lucian Arye Bebchuk, A Rent-Protection Theory of Corporate Ownership and Control (Nat'l Bureau of Econ. Research, Working Paper No. 7203, 1999), available at http://www.nber.org/papers/ w7203. However, data show this was not the case. See Érica Gorga, Corporate Control \& Governance after a Decade from "Novo Mercado": Changes in Ownership Structures and Shareholder Power in Brazil, in RESEARCH HANDBOOK on Shareholder Power (Jennifer G. Hill \& Randall S. Thomas eds., forthcoming 2015).

9 See generally Ryan Avent, The Euro Crisis: The New European Union, Economist, Dec. 16, 2013, http://www.economist.com/blogs/freeexchange/2013/12/euro-crisis; Mark Landler, The U.S. Financial Crisis Is Spreading to Europe, N.Y. TimES, Sept. 30, 2008, http://www.nytimes.com/2008/10/01/business/worldbusiness/01global. html?_r=0; Bill Marsh, It's All Connected: A Spectator's Guide to the Euro Crisis, 
numbers, one might underestimate the impact of the international crisis on Brazil's capital markets and corporate governance practices. In spite of the trivial decline in securities prices (as experienced in virtually every stock market), an unexpected development followed.

Two leading Brazilian corporations - Sadia S.A. and Aracruz Celulose S.A. - suffered billion-dollar losses when the Brazilian real unexpectedly plummeted in relation to the dollar, causing severe financial turmoil. ${ }^{10}$ These nonfinancial companies had previously disclosed that they followed conservative financial policies and relied on hedging instruments to manage risk exposure to exchange rate fluctuations as part of their normal international commercial activities. However, their actual losses were far greater than what would have been expected from pure hedging activity protecting the revenues of core business operations. Instead, the sudden losses were found to be the result of the companies' highly speculative trading in the currency derivatives futures markets. ${ }^{11}$ These developments were largely exposed in media cover stories, prompting strong criticisms by market players and politicians, including the Brazilian president at the time. ${ }^{12}$

N.Y. Times, Oct. 22, 2011, http://www.nytimes.com/imagepages/2011/10/22/ opinion/20111023_DATAPOINTS.html?ref=sunday-review; Jonathan Davis, One of the Worst Handled Crises Ever, Fin. Times Opinion Blog (May 20, 2012, 4:28 AM), http://www.ft.com/intl/cms/s/0/ef9cb1f4-a030-11e1-90f3-00144feabdc0. html? siteedition=intl\#axzz2pA1SJ8FL.

10 Commentators pointed out that many other Brazilian companies also suffered losses with currency exchange derivatives. In this Article I focus only on the two most egregious and widely discussed cases. See infra note 39.

11 The Brazilian firms therefore contradicted academic findings for a sample of U.S. nonfinancial firms. See Wayne Guay \& S.P. Kothari, How Much Do Firms Hedge with Derivatives?, 70 J. FIN. Econ. 423 (2003) ("Corporate derivatives use appears to be a small piece of non-financial firms' overall risk profile."); see also Ludger Hentschel \& S.P. Kothari, Are Corporations Reducing or Taking Risks with Derivatives?, 36 J. Fin. \& Quantitative Analysis 93 (2001). For a recent critique of the the Dodd-Frank Act's financial regulation, see Gina-Gail S. Fletcher, Hazardous Hedging: The (Unacknowledged) Risks of Hedging with Credit Derivatives, 33 Rev. Banking \& Fin. L. 813 (2014).

12 Brazilian President Luiz Inácio Lula da Silva declared: "The companies that bet and lost will have to face up to their responsibilities." Antonio Regalado, Big Currency Bets Backfire, WaLl ST. J., Oct. 22, 2008, http://online.wsj.com/ news/articles/SB122463251866656551. He also affirmed that "[i]t was not because of the crisis, but because of speculation. They were speculating against the Brazilian currency. They were practicing, through greed, speculation that is in no way recommendable." Lula acusa Aracruz e Sadia de especulação gananciosa [Lula Accuses Aracruz and Sadia of Greedy Speculation], EsTADÃo, 
Consequently, several private suits were filed both in the United States and in Brazil. U.S. lawyers filed federal class actions in New York and Florida on behalf of American Depositary Receipt (ADR) holders, claiming securities fraud on the grounds that the companies were heavily speculating in currency rates in amounts that largely exceeded any prudent hedging. In shareholder meetings, Brazilian shareholders authorized the corporations to file "derivative" lawsuits against former Chief Financial Officers in São Paulo and Rio de Janeiro. ${ }^{13}$

In this Article, I take a novel approach to the transnational securities litigation debate by examining the particular consequences of private litigation in the United States and in Brazil. I focus on the distinct private enforcement actions taken in a developed and in an emerging country against both companies and their managers. The settlement hearings for the Sadia and Aracruz cases have recently been conducted in the United States, ${ }^{14}$ and the legal actions in Brazil have also concluded. Therefore, I am able to compare their legal nature and developments, as well as their final outcomes.

While the alleged wrongdoings were generally the same, similarly affecting American and Brazilian securities holders of Sadia and Aracruz, the legal mechanisms available for investor protection and their outcomes were strikingly different in the two jurisdictions. For both companies, only U.S. investors were able to obtain financial recoveries. The Sadia U.S. suit was settled for $\$ 27,000,000$ and the Aracruz U.S. suit for $\$ 37,500,000$. In contrast, Brazilian investors recovered nothing from those companies. This is because, as I discuss, there are no appropriate legal mechanisms in Brazil that enable direct investor indemnification by Sadia and Aracruz. Because of the lack of private class action avenues, investors had to rely on "derivative" suits, which provided only a small recovery to the company, rather than to its investors. Even if one considers that the recovery values obtained by U.S. ADR investors were relatively low, the Sadia and Aracruz cases provide concrete examples of the financial value distributions that characterize the current system of transnational

Oct. 4, 2008, http://economia.estadao.com.br/noticias/geral,lula-acusa-aracruze-sadia-de-especulacao-gananciosa,253360.

13 I conduct a comprehensive comparative case-study of the private and public enforcement actions and their factual backgrounds in the United States and in Brazil in a companion article. See Érica Gorga, Is the U.S. Law Enforcement Stronger Than That of a Developing Country? The Case of Securities Fraud by Brazilian Corporations and Lessons for the Private and Public Enforcement Debate (Oct. 22, 2014) (unpublished manuscript) (on file with author).

14 The hearing of the Aracruz settlement took place on July 17, 2013. The Sadia case had already received the order authorizing distribution of the net settlement fund on February 26, 2013. 
securities litigation. They allow a broader assessment of the type of wealth transfers that affect the whole universe of cross border litigation and with implication to much larger and more frequent wealth transfers.

This Article discusses the economic and legal problems in the global securities markets stemming from such potentially discrepant results. The fact that investors holding securities from the same companies suffered similar damages but were subject to such distinct legal remedies raises efficiency and fairness concerns for international securities markets. In fact, I show that the Brazilian investors bore most of the costs of the settlement payments to U.S. investors. ${ }^{15}$ Further, U.S. investors also indirectly benefited from the Brazilian derivative suit in one of the cases. In this way, the disparity between the U.S. and Brazilian legal rules and enforcement governing private securities litigation led to a transfer of financial value from the Brazilian companies exclusively to U.S. investors.

This type of wealth transfer not only includes the typical "circularity problem" in securities litigation, ${ }^{16}$ which refers to the fact that innocent shareholders who did not contribute to the securities fraud bear the costs of compensation to the investors who lost value. ${ }^{17}$ The standard circularity problem supposes that those innocent shareholders who will compensate the class certified by the class action suit were not victims of the same fraud. The problem with the current regime of transnational securities litigation is more severe because, in addition to the classical circularity problem, it comprises an extra level of double taxation on foreign shareholders who already suffered from the same fraud, are not being compensated for their financial losses,

15 In this Article, the expression "U.S. or American investors" refers to investors who acquired securities in the United States. Likewise, "Brazilian or foreign investors" are those who acquired securities in Brazil or elsewhere outside the United States. I adopt Morrison's rationale of referring to the geographical location where the transaction occurred, instead of the purchaser's or seller's nationality. See Morrison v. Nat'l Austl. Bank Ltd., 130 S. Ct. 2869 (2010). One has to concede that it is more often the case that the nationality of investors overlaps with the place in which they acquire securities, although this is not necessarily so. These were the cases of Sadia and Aracruz, in which the investors who acquired shares in the United States, lead plaintiffs of the class actions, were American pension funds and groups of investors.

16 The classic "circularity problem" in securities litigation was analyzed by John C. Coffee, Jr., Reforming the Securities Class Action: an Essay on Deterrence and Its Implementation, 106 Colum. L. REv. 1534, 1538 (2006) (“'[S]ecurities litigation imposes costs on investors because of harm done to investors - without recognizing that the victim is again bearing the costs of its own injury.").

17 Id. at 1536 n.5. 
and still bear the pro rata burden of payment to U.S. investors. This scenario constitutes a "double circularity problem" for foreign shareholders who suffered equivalent damages to the U.S. class that is being compensated. This double circularity problem thus raises the question of whether foreign securities holders should bear twice the costs of failures of a company's corporate governance practices.

In addition to private enforcement variation, to be sure, public enforcement relative to the Sadia and Aracruz cases was also contrasting in the U.S. and the Brazilian markets. While the U.S. Securities and Exchange Commission (SEC) did not take action, administrative proceedings filed by Comissão de Valores Mobiliários (CVM), the Brazilian securities regulator, resulted in fines and settlement payments by Brazilian board members and officers. ${ }^{18}$ In this respect, one could argue that once public enforcement actions differ across jurisdictions, private enforcement actions should also be expected to vary. ${ }^{19}$ Notwithstanding, while differences in overall intensity of enforcement across countries have been acknowledged - and to some extent promoted ${ }^{20}$ - by the literature, public enforcement actions are less likely to facilitate wealth transfers between jurisdictions than private actions are. As the Sadia and Aracruz cases show, the Brazilian public enforcement actions did not result in financial compensation to securities holders. ${ }^{21}$ Therefore, once this

18 See Gorga, supra note 13 (discussing public enforcement actions in Brazil, and the lack of actions in the United States). One officer was forbidden to hold a managerial position for specific time.

19 I acknowledge that public and private enforcement are parts of a total system of investor protection offering compensation and deterrence, and that they can both substitute or complement one another. I thank Roberta Romano for raising this issue. Nonetheless, I focus on the analysis of private enforcement actions in this Article because their resulting distributional effects across countries are currently more significant. If public enforcement actions also result in distributional problems among securities holders of the same issuer, I believe that the same arguments advanced in this Article can largely apply. Current available evidence shows that some types of public enforcement actions may result in wealth transfers to U.S. investors. See Urska Velikonja, Public Compensation for Private Harm: Evidence from the SEC's Fair Fund Distributions, 67 STAN. L. REV. (forthcoming 2015), available at http://ssrn.com/abstract=2400189. In this vein, public enforcement actions might also aggravate the wealth transfer effects in transnational securities markets, which this Article discusses, depending on who bears their costs - the company or individual managers.

20 Defendants of the limits of extraterritoriality effects of the U.S. securities law regime have, in this sense, defended the ability of different jurisdictions to tackle securities fraud as they see fit. See infra notes 25-26.

21 See Gorga, supra note 13, Section V. 
Article analyzes the distributional effects in international markets generated by securities law enforcement, ${ }^{22}$ it primarily focuses on private actions, in which these issues seem to be more relevant at present.

The Sadia and Aracruz outcomes demonstrate the practical flaws of the existing transnational regime of private securities litigation. These flaws were later substantially exacerbated by the U.S. Supreme Court's decision in Morrison v. National Australia Bank Ltd.,${ }^{23}$ which excluded the cause of action previously available to f-cubed claims based on the U.S. antifraud securities regime. ${ }^{24}$ Morrison's transactional test has echoed the locationbased rule proposed by several scholars. ${ }^{25} \mathrm{~A}$ substantial academic literature has been produced regarding the extraterritoriality of the U.S. securities law regime previously and especially in the wake of Morrison. In fact, a number of scholars have criticized the extraterritoriality of U.S. antifraud provisions due to increased costs and economic harm to foreign issuers and investors, as well as pernicious political impact on U.S. international relations. ${ }^{26}$

22 Distributive and allocative effects in the corporate control market have already attracted the attention of corporate law scholars discussing antitrust concerns. See generally Edward B. Rock, Antitrust and the Market for Corporate Control, 77 CALif. L. Rev. 1365, 1372 n.13 (1989) (discussing the relevant literature on distribution of wealth in antitrust analysis and fairness concerns embodied in antitrust laws).

23 Morrison v. Nat'l Austl. Bank Ltd., 130 S. Ct. 2869 (2010).

24 Foreign cubed or simply f-cubed litigation refers to actions brought in the United States against foreign issuers of securities on behalf of foreign investors who acquired the securities on a foreign exchange. See infra Part II for a discussion of Morrison.

25 See Hannah L. Buxbaum, Multinational Class Actions Under Federal Securities Law: Managing Jurisdictional Conflict, 46 Colum. J. Transnat'L L. 14, 15 (2007-2008) (defending a "jurisdictional limit based on the location of investment transactions" for foreign-cubed claims); Stephen J. Choi \& Linda J. Silberman, Transnational Litigation and Global Securities Class-Action Lawsuits, 2009 WIS. L. REv. 465, 596 ("Courts should presume jurisdiction over all investors trading in a foreign issuer's securities within the United States, and presume no jurisdiction over 10b-5 suits for foreign investors trading in the securities of a foreign issuer outside the United States."); Erez Reuveni, Extraterritoriality as Standing: A Standing Theory of the Extraterritorial Application of the Securities Laws, 43 U.C. DAvis L. REv. 1071, 1072 (2010) (“"[O]nly foreign investors who purchase or sell stock in the United States have standing to invoke the securities laws.").

26 Stephen J. Choi \& Andrew T. Guzman, The Dangerous Extraterritoriality of American Securities Law, 17 Nw. J. INT'L L. \& Bus. 207, 208 (1996-1997) (pointing out "conflicts between the United States and other nations."); Stephen 
Most of the literature, however, has focused on theoretical analysis to conclude that there are generic "costs" associated with the extraterritorial effects of the U.S. regulation and to propose policy reforms to reduce them. When featuring case studies on actual litigation results, the literature has been restricted exclusively to analysis of cases and outcomes in the United States. ${ }^{27}$ It has neglected the development and outcome of cases in the issuer's foreign jurisdiction whose securities regime wrongdoers are also subject to. The literature therefore is bereft of qualitative case studies comparing the outcomes across jurisdictions achieved by private litigation based on the same type of alleged corporate wrongdoing.

The practical result of this surprising focus has heretofore been to prevent scholars and regulators from distinguishing which costs they are referring to. By generically labeling "costs," scholars conflate costs to American markets, American investors, foreign issuers, and foreign investors, as if these costs were always the same or directly additive as opposed to canceling each other. ${ }^{28}$ Furthermore, they have aggregated costs stemming from micro securities transactions and macro costs allegedly created by the externalities of these transactions to the entire system. ${ }^{29}$ These aggregated costs are then compounded in magnitude to warrant a policy prescription intended to diminish them - all without precisely specifying which costs that policy aims to mitigate, who bears those costs, and whose pockets will be spared.

J. Choi \& Andrew T. Guzman, Portable Reciprocity: Rethinking the International Reach of Securities Regulation, 71 S. CAL. L. REv. 903, 914 (1998) (arguing that the extraterritorial effects of U.S. securities regulation would "multiply the costs to investors and issuers"); Jill E. Fish, Imprudent Power: Reconsidering U.S. Regulation on Foreign Tender Offers, 87 Nw. U. L. Rev. 523, 523, 554 (1993) (arguing that the U.S. expansive jurisdiction "has proven costly" and that courts must consider "the political impact of applying U.S. law on international relations, U.S. foreign policy, and the development of multinational business"); see also Reuveni, supra note 25, at 1077.

27 See Yuliya Guseva, Cross-Listings and the New World of International Capital: Another Look at the Efficiency and Extraterritoriality of Securities Law, 44 Geo. J. InT'L. L. 411 (2013) (surveying seventy-five legal cases against foreign private issuers brought in the United States).

28 See supra notes 25-27.

29 See, e.g., Fish, supra note 26, at 523-24 (adding up generic political costs of the U.S. policy with economic costs from uncertainty produced to foreign business transactions, the result of which "may ultimately hurt American investors"). Missing in this approach is a specification of who bears each cost and whether they would simply all add up to ultimately compound the effects on American investors. 
In this Article I call attention to this current methodological flaw and argue that the academic literature, as well as regulators,$^{30}$ has neglected particular costs stemming from the economic distribution resulting from private litigation in multiple jurisdictions, as occurred in the Aracruz and Sadia cases. ${ }^{31}$ In this respect, I take a differentiated and specific methodological approach, focusing on the distributional costs and welfare effects produced by Morrison. Based on these case studies, I show that the current Morrison rationale of banning U.S. securities law protections to f-cubed claims, contrary to the common academic assessment, ${ }^{32}$ raises substantially the costs borne by foreign investors from cross-listing in the United States. In fact, these investors, who usually don't enjoy the same antifraud protections overseas - due to the lack of appropriate law or enforcement mechanisms - are compelled to accept, to their detriment, wealth transfers from their investment to U.S. investors. In this fashion, Morrison leads to (i) non pro rata shareholder compensation, and (ii) wealth transfers from foreign to U.S. investors.

These specific costs borne by foreign investors must be added to the general welfare equation used to orient international policy prescriptions. They should be taken into account in the strategic decisions of securities holders and issuers as well as regulators. To cope with this problem, the Article turns to potential solutions to the current transnational securities litigation system. It reviews reform proposals to assess which could diminish wealth transfers or provide uniformity of legal results and remedies for shareholders who have suffered equivalent harms, thus minimizing distributional effects in international capital markets. These proposals would harmonize the impact of corporate governance failures among securities holders across different jurisdictions.

The Article proceeds as follows. Part I describes the Sadia and Aracruz cases, discussing the factual background and contrasting the legal mechanisms and results of the private suits in the United States and in Brazil. Part II reviews the Morrison decision and the academic literature produced in its aftermath, presenting a critical analysis of the current debate and reform proposals. Part III uses the outcomes from the Sadia and Aracruz litigations to discuss problems with the current system of transnational securities litigation. I show

30 See, e.g., U.S. Sec. \& Exchange Comm'n, Study on the Cross Border Scope of the Private Right of Action Under Section 10(в) of the Securities Exchange Aст OF 1934 (2012), available at http:/www.sec.gov/news/studies/2012/929ystudy-cross-border-private-rights.pdf. See infra Part II for further discussion about the regulatory and scholarly focus.

31 A number of other cases also corroborate my arguments. See, for example, the discussion of the German Telekom case infra notes 143-144 and accompanying text.

32 See sources cited supra note 26. 
that Morrison aggravates the wealth transfers brought to light by the Sadia and Aracruz cases and by other examples such as the German Telekom case. I further contend that the market solution does not convincingly tackle the problem. Part IV reviews reform proposals, inquiring as to whether they address these current failures. One possibility is a reform in the U.S. system of private litigation that would overrule Morrison. Another alternative is to rely on reforms in foreign jurisdictions that could provide private enforcement mechanisms to foreign investors, so as to minimize wealth transfers to U.S. investors. Because of the shortcomings associated with the implementation and results of these proposals, the Article then endorses a different set of private ordering reforms that would yield the same legal outcomes for both U.S. and foreign securities holders, thus achieving pro rata compensation to all damaged investors. The last Part concludes.

\section{The Sadia ANd Aracruz Cases}

Sadia S.A. and Aracruz Celulose S.A. were both major exporting companies, considered Brazilian industrial champions. Sadia operated in the food and beverages industry, selling its products throughout Latin America, the Middle East, Asia, and Europe.$^{33}$ Aracruz was a major forest products manufacturer and the world's biggest eucalyptus pulp producer. ${ }^{34}$ Both companies were listed on the Brazilian stock exchange BM\&FBovespa, Level 1 listing segment. ${ }^{35}$ Both companies had sponsored ADRs programs on the New York Stock Exchange (NYSE). Sadia had listed Level II ADRs on the NYSE, as well as on the Spanish Market for Latin-American Stocks in Euros (LATIBEX) ${ }^{36}$ Aracruz, in its turn, had listed on the NYSE Level III ADR program.

\section{A. Factual Background}

Because the two companies were exposed to exchange rate fluctuations due to their regular business operations, they usually engaged in hedging to protect

33 See Kenneth Rapoza, CFO Who Laid Low Brazil's Sadia: Blame It on Lehman, Dow Jones Newswires (Apr. 17, 2009), http://www.advfn.com/nyse/StockNews. asp? stocknews $=$ PDU\&article $=37334277 \&$ headline $=$ cfo-who-laid-low-brazilssadia-blame-it-on-lehman.

34 See Carlos Caminada, Aracruz Slumps Most in 14 Years on Derivatives Loss (Update2), BloOMBerg (Oct. 3, 2008), http://www.bloomberg.com/apps/news ?pid=newsarchive $\&$ sid $=\mathrm{a} 4 \mathrm{pPZj} 1 \mathrm{QIZhM}$.

35 See supra note 6.

36 I was not able to find any private actions connected to the LATIBEX securities on the Spanish market. 
their cash flows. Between 2004 and mid-2008 the Brazilian currency — the real - continuously appreciated against the U.S. dollar. Hoping that the trend would continue, many companies began speculating with derivative instruments offered by financial institutions - the so-called Sell Target Forward (STF) contracts. ${ }^{37}$

Both companies had affirmed in their disclosure materials in Brazil and in the United States that they relied on hedging instruments to protect against risk exposure to exchange rate fluctuations. They stated that their currency contracts did not represent substantial economic or financial risks to investors. ${ }^{38}$ However, the global financial crisis resulted in the sudden appreciation of the dollar against the real, inflicting on Sadia and Aracruz - as well as many other companies ${ }^{39}$ - massive mark-to-market losses. ${ }^{40}$ Their share prices fell

37 Carlos Caminada \& Adriana Brasileiro, Aracruz Faces \$2.13 Billion Deadline Over Derivatives, BloomBerg (Dec. 11, 2008), http://www.bloomberg.com/ apps/news?pid=newsarchive\&sid=aSwbsXO7zIRU\&refer=news. Banks like Citigroup Inc., Merrill Lynch \& Co., Barclays Plc, Banco UBS Pactual SA, Deutsche Bank AG, and others sold the derivatives.

38 Consolidated Amended Complaint at 17-22, In re Sadia, S.A. Securities Litigation, 643 F. Supp. 2d 521 (S.D.N.Y. 2009), No. 1:08-cv-09528 (S.D.N.Y. Mar. 16, 2009); ECF No. 25. Amended Class Action Complaint at 20, City Pension Fund for Firefighters and Police Officers in the City of Miami Beach v. Aracruz Celulose S.A., 1:08-cv-23317 (Oct. 5, 2009), ECF No. 30. See Gorga, supra note 13 Section III, for detailed factual description.

39 See, e.g., Braskem perde R\$ 849 milhões [Braskem Loses $R \$ 849$ Million], O Estado de São Paulo [State of São Paulo], Nov. 6, 2008, http://economia. estadao.com.br/noticias/geral,braskem-perde-r-849-milhoes,273259; Mariana Barbosa, Vicunha negocia com bancos liquidação de derivativos [Vicunha Negotiates with Banks Derivatives Liquidation], O Estado de São Paulo [State of São Paulo], Nov. 3, 2008, at B12; Mariana Barbosa, Votorantim perde R\$ 2,2 bi com derivativos [Votorantim Loses $R \$ 2.2$ Billion with Derivatives], $\mathrm{O}$ Estado de São Paulo [State of São Paulo], Oct. 11, 2008, at B14; Lilian Cunha, Ajinomoto tem perda de R\$ 180 mi com câmbio [Ajinomoto Has Loss of R\$ 180 Million with Exchange Rates], Valor EConômico [Econ. VAlue], Jan. 20, 2009, at C1; David Friedlander \& Marianna Aragão, Tok \& Stok é vítima dos derivativos [Tok \& Stok Is a Victim of Derivatives], O Estado de São Paulo [State of São Paulo], Jan. 25, 2009, at B10; Marli Olmos \& Graziella Valenti, Embraer tem perda com o dólar mas espera reversão [Embraer Loses with the Dollar, But It Expects a Reversal], VAlor Econômico [Econ. VAlue], Nov. 5, 2008, at D3.

40 Caminada \& Brasileiro, supra note 37 . The value of the dollar abruptly appreciated thirty-three percent against the real. 
sharply. As a result, the accumulated losses of Sadia and Aracruz reached around 1.1 and 2.13 billion dollars, respectively. ${ }^{41}$

\section{B. U.S. Private Suits}

Shortly after these great losses, federal securities class actions were filed in New York and Florida. On November 5, 2008 lead plaintiffs "the Sadia Investor Group" filed a complaint against Sadia S.A. and certain managers in the United States District Court for the Southern District of New York. ${ }^{42}$ On November 26, 2008, City Pension Fund for Firefighters and Police Officers in the City of Miami Beach (hereafter referred to as "Miami Beach") filed a complaint against Aracruz Celulose S.A. and certain managers in the United States District Court for the Southern District of Florida, Miami Division. ${ }^{43}$

Both complaints asserted that the companies' great losses could not be explained by pure hedging activity and that defendants misrepresented the nature and extent of their currency hedging strategies in their 6-K Forms. They alleged that the wild bets in the derivatives markets contradicted the companies' policies, public statements, and disclosure materials. The companies and their executives were gambling away shareholder money in highly volatile currency investments; and senior executive officers and/or directors knew, or recklessly disregarded, that adverse facts were hidden from the investor public. ${ }^{44}$ As a

41 Caminada \& Brasileiro, supra note 37; Tatiana Freitas, Derivativo leva Sadia a prejuizo de $R \$ 2,5$ bi [Derivative Causes Sadia a Loss of $R \$ 2.5$ Billion], O Estado de São Paulo [State of São Paulo], Mar. 28, 2009, http://economia. estadao.com.br/noticias/geral,derivativo-leva-sadia-a-prejuizo-de-r-2-5-bi,346128. $\mathrm{R} \$ 2.5$ billion is equivalent to $\$ 1,099,142,750$, using the dollar exchange rate provided by Brazilian Central Bank on Mar. 28, 2009.

42 Plaintiffs included Westchester Putnam Counties Heavy \& Highway Laborers Local 60 Benefit Funds, Alan Hyman, Phil Carey, Steve Geist and Peter Stricker. Consolidated Amended Complaint, In re Sadia, 643 F. Supp. 2d 521, at*41. Defendants included Luiz Fernando Furlan, Chairman; Gilberto Tomazoni, Chief Executive Officer (CEO) during the class period; Welson Teixeira, Jr., Chief Financial Officer (CFO); Adriano Lima Ferreira, CFO during the class period; Walter Fontana Filho, former company's CEO and Chairman; Eduardo Fontana d'Avila, company's Vice Chairman during the class period.

43 Amended Class Action Complaint, Aracruz, No. 1:08-cv-23317, at*49. Defendants included Carlos Alberto Vieira, former Chairman of Aracruz, Carlos August Lira Aguiar, CEO during the class period, and Isac Roffé Zagury, CFO during the class period.

44 Id. at *50; Consolidated Amended Complaint, In re Sadia, 643 F. Supp. 2d 521, at $* 37$. 
consequence of the false disclosure, the prices of Sadia and Aracruz ADRs were inflated during the class period, causing financial injury to members of the class when the prices later dropped. ${ }^{45}$ Plaintiffs then alleged violations of section 10(b), including Rule 10b-5 promulgated thereunder, and section 20(a) of the Securities Exchange Act of 1934. ${ }^{46}$

Plaintiffs and defendants agreed to settle the Sadia litigation for a cash value of $\$ 27,000,000 .{ }^{47}$ In a memorandum opinion and order issued on December 28,2011 , the court approved the settlement as in the best interests of the class. The attorneys' fees were established as thirty percent of the net settlement fund $(\$ 8,100,000)$, plus $\$ 723,228.36$ in expenses and interest. ${ }^{48}$ The balance of the net settlement fund was $\$ 18,012,711.96$ on January 31,2013 , to be distributed to U.S. class members. ${ }^{49}$

45 Amended Class Action Complaint, Aracruz, No. 1:08-cv-23317, at*42-43; Consolidated Amended Complaint, In re Sadia, 643 F. Supp. 2d 521, at *5-7.

46 Consolidated Amended Complaint, In re Sadia, 643 F. Supp. 2d 521, at*3, 22; Amended Class Action Complaint, Aracruz, No. 1:08-cv-23317, at*13, $24,42$.

47 My focus in this Part is mainly on the final outcomes of the cases. See Gorga, supra note 13, Section IV (examining the suits' details such as procedural developments, substantive arguments, and court decisions). For a detailed discussion of the settlement negotiations, see Joint Declaration of Joseph E. White III and Jennifer L. Enck in Support of Class Representatives' Motion for Distribution of Net Settlement Fund, In re Sadia, 643 F. Supp. 2d 521, at *16-17.

48 The judge reviewed and lowered attorney's requested rates for support staff and eliminated fees for non-lawyer investigatory work, approving a $\$ 7,797,961.50$ lodestar fee corresponding to approximately 20,530 work hours. The expenses $(\$ 723,228.36)$ total approximately three percent of the value of the settlement. The court also awarded an additional $\$ 14,177.50$ to class representatives for their related costs and expenses. In re Sadia, 643 F. Supp. 2d 521.

49 Joint Declaration of Joseph E. White, III and Jennifer L. Enck in Support of Class Representatives' Motion for Distribution of Net Settlement Fund, In re Sadia, 643 F. Supp. 2d 521, at*3. During the specified class period, approximately $14,900,000$ Sadia ADRs were acquired and potentially damaged. The average recovery, according to the settlement agreement, amounted to $\$ 1.81$ per allegedly damaged ADR, before deductions of court-approved costs and attorneys' fees. The average cost per damaged ADR was estimated at $\$ 0.66$ before the court approval of attorney fees. As the judge established a smaller fee percentage (thirty percent) than the one requested by the lawyers $(33.33 \%$, the final value should have decreased. See Exhibit 1, Exhibit A, Notice of Pendency of Class Action and Proposed Settlement, Motion for Attorney's Fees and Expenses and Settlement Fairness Hearing, In re Sadia, 643 F. Supp. 2d 521, at*1-2. One could then raise the point that significant wealth transfers were also made to the 
After incurring such great financial losses, Sadia S.A. was forced to consolidate with Perdigão S.A., and both corporations were succeeded by BR Foods S.A. ${ }^{50}$ BR Foods later disclosed that the payment of the settlement was made with Sadia's operating income. ${ }^{51}$

plaintiffs' attorneys. Coffee, supra note 16 at 1538 (“'[A] significant percentage of the transfer payment goes to lawyers and other agents.").

50 Antonio Regalado \& Lauren Etter, Perdigão Strikes Deal with Sadia, Wald ST. J., May 21, 2009, http://online.wsj.com/articles/SB124273713892234345 ("The deal was forced by financial troubles. Both firms posted quarterly losses this year on a drop of exports, and Sadia has struggled after huge losses on currency bets last year left it burdened by debt."). Perdigão S.A. has also been cross-listed on the NYSE since 2000. One could then argue that both Brazilian and American investors paid for the settlement amounts and thus the wealth transfer did not impose a burden solely on the Brazilian domestic market. While I acknowledge this point, two caveats are important. First, BR Foods Level III ADRs, which trade on the NYSE and now reference ordinary shares, represented approximately only thirteen percent of the company's ordinary shares from 2012 and 2013 when the settlement payment was processed. See BR Foods S.A., Formulários de Referência [Reference Forms], CVM (Apr. 18, 2013), https://www.rad.cvm.gov.br/enetconsulta/frmGerenciaPaginaFRE. aspx CodigoTipoInstituicao $=1 \&$ NumeroSequencialDocumento=26193; BR Foods S.A., Formulários de Referência [Reference Forms], CVM (Apr. 16, 2014), https://www.rad.cvm.gov.br/enetconsulta/frmGerenciaPaginaFRE.aspx? CodigoTipoInstituicao $=1 \&$ NumeroSequencialDocumento $=36278$. Second, and most importantly, as I further discuss in Part III below, the circularity problem in this case presents a multiplier component, as the costs also fall on Brazilian shareholders who suffered the underlying securities fraud.

51 Brasil Foods S.A., Demonstrações Financeiras [Standard Financial StatemEnTs] 162 (2011), available at http://www.brasilfoods.com/ri/siteri/web/arquivos/ dfp2011_en.pdf:

The subsidiary Sadia and some of its current and former executives were named as defendants in five class actions suits arising from investors of American Depositary Receipts ("ADRs") issued by Sadia and acquired in the period from April 30, 2008 to September 26, 2008 (Class Period). ... During the second semester of 2011, the Company reached a final agreement with the plaintiffs homologated by the U.S. judicial authority and as a consequence settled the case with a payment of US\$27,000. The Company's [sic] previously recorded a provision superior to the amount of the settlement, therefore, a reversal in the amount of $\mathrm{R} \$ 118,684$ was recorded in the other operating income.

According to this statement, the company relied on Sadia's operating income to pay the settlement, and not on the D\&O insurer policy eventually in place at the time. 
Therefore, the Sadia lawsuit resulted in a wealth transfer from investors of the successor company to Sadia's ADR investors in the United States as compensation for those investors' damages. Furthermore, as I discuss below, the Brazilian shareholders who acquired preferred shares in the Brazilian market equivalent to the ones in custody with the U.S. ADR program sponsor ultimately received no compensation for the equivalent financial harm they suffered.

The Aracruz suit led to similarly non pro rata distributions, despite some procedural differences in relation to the Sadia litigation. ${ }^{52}$ The parties reached a settlement agreement for a $\$ 37,500,000$ cash payment compensating Aracruz ADRs investors. The court then approved the settlement and its allocation plan, as well as certifying the plaintiff class. It awarded the plaintiffs' lawyers $33.33 \%$ in attorneys' fees, which corresponded to $\$ 12,500,000$ of the settlement fund. ${ }^{53}$ It also allowed reimbursement of $\$ 839,703.18$ in lawsuit expenses and a $\$ 40,000$ award for reasonable costs and expenses incurred in representing the class. $^{54}$

On December 31, 2009, Aracruz merged into Fibria Celulose S.A. (formerly Votorantim Celulose e Papel), with Fibria as the surviving entity. ${ }^{55} \mathrm{~A}$ report

52 See Gorga, supra note 13, Section IV.2.

53 Lead Plaintiff's Motion for Final Approval of Settlement and Award of Attorneys' Fees and Reimbursement of Expenses and Incorporated Memorandum of Law in Support, Aracruz, No. 1:08-cv-23317, at*57. See supra text accompanying note 49 , regarding wealth transfers to U.S. attorneys.

54 Id.; see Exhibit A, Notice of Pendency of Class Action and Proposed Settlement, Motion for Attorneys' Fees and Expenses and Settlement Fairness Hearing, Aracruz, No. 1:08-cv-23317, at*2. During the class period, 11,000,000 Aracruz ADRs were traded and the average recovery under the settlement amounted to \$3.41 per allegedly damaged ADR, before deductions of court-approved costs and attorneys' fees. The requested fees would amount to "an average of $\$ 1.13$ per allegedly damaged ADR."

55 On August 27, 2009 a 6-K form filed with the SEC announced a shareholders' meeting had approved the merger of Aracruz with Votorantim Celulose e Papel S.A. See Carlos Caminada, Aracruz, VCP to Merge, Form Top Eucalyptus-Pulp Maker (Update2), BloOMBERG (Sept. 15, 2008), http://www.bloomberg.com/ apps/news?pid=newsarchive\&sid=a.0ZRPotKneA. Fibria is also cross-listed on the NYSE, negotiating Level III ADRs lastly issued in 2012. It negotiated approximately fifty-one percent and forty-six percent of its securities in the United States in 2012 and 2013, respectively. See Fibria Celulose S.A., Formulários de Referência [Reference Forms], CVM (Mar. 28, 2013), https://www.rad.cvm. gov.br/enetconsulta/frmGerenciaPaginaFRE.aspx?CodigoTipoInstituicao $=1 \&$ NumeroSequencialDocumento=25697; Fibria Celulose S.A., Formulários de Referência [Reference Forms], CVM (Mar. 26, 2014), https://www.rad.cvm. 
from the administration commenting on the 2012 financial statements of Fibria stated that the costs of the U.S. Aracruz litigation were "significantly" supported by Fibria's Directors and Officers (D\&O) insurance policy. ${ }^{56}$

Because Fibria disclosed that its D\&O insurance policy covered most of the lawsuit costs, one could then argue that Aracruz's Brazilian investors did not support the costs of the Aracruz settlement to the same extent that Sadia's Brazilian investors did. However, although scholars report that "[a]lmost all shareholder litigation settles within the limits of available D\&O insurance,",57 Brazilian investors still bore the costs of the $\mathrm{D} \& \mathrm{O}$ insurance coverage. These costs are driven by two variables: first, the value of deductibles for large companies is hardly negligible, reaching the millions; $;{ }^{58}$ and second, deductibles may increase after a claim is submitted.

Another observation concerns the impact of currency exchange on the costs of the U.S. litigations for Brazilian investors. Because the dollar is overvalued in relation to the Brazilian reals, ${ }^{59}$ any payment made in connection to a U.S. legal expense has to be multiplied by the actual currency rate in order to reflect the real value supported by Brazilian investors. For instance, as disclosed by Fibria, the $\$ 37,500,000$ payment to ADR holders corresponded to $\mathrm{R} \$ 76,600,000$ after currency exchange conversion. This is to say that in

gov.br/enetconsulta/frmGerenciaPaginaFRE.aspx?CodigoTipoInstituicao $=1 \&$ NumeroSequencialDocumento $=35525$. For a discussion regarding the burden of costs, see supra note 50.

56 Fibria Celulose S.A., Demonstrações Financeiras [Consolidated Financial STATEMENTS] 3, 50 (2012), avalaible at http://www.fibria.com.br/rs2012/fibriafinancial-statements-2012.pdf:

In December, Fibria ratified an agreement in respect of class action suit brought against the Company in November of 2008 by potential ADR buyers from April 7 to October 2, 2008 . . . Under the agreement, the Company and its co-defendants agreed to pay a total of US\$37.5 million to all the ADR holders during the period mentioned above. Because Fibria has Directors and Officers (D\&O) insurance with cover extending to the company that will reimburse a significant part of this expense, there will be no material effect on the company.

57 Tom Baker \& Sean J. Griffith, The Missing Monitor in Corporate Governance: The Directors' \& Officers'Liability Issuer, 95 Geo. L.J. 1795, 1806 (2006-2007).

58 Id. at $1819,1824 \mathrm{n} .144$ (reporting deductibles of $\$ 8,900,000$ for large corporations in 2005).

59 See the historical evolution of the official U.S. dollar exchange rate to the Brazilian real at the BraziLian CENT. BANK Sys., http://www4.bcb.gov.br/pec/taxas/port/ ptaxnpesq.asp?id=txcotacao (last visited Aug. 31, 2014). To illustrate, in 2008 the value of one dollar in reais oscillated from a low of $\mathrm{R} \$ 1.55$ on August 1 to a high of $\mathrm{R} \$ 2.49$ on December 5, after the crisis hit. 
any case, it is more expensive for Brazilian investors to pay expenses in dollars than in Brazilian reals. Once their securities investment was made in reals, they also bore a disproportional exchange rate for the costs of all legal outcomes in the United States.

Finally, even if one accepts that D\&O insurance has absorbed some of the costs of the U.S. Aracruz settlement imposed on Brazilian investors, American ADR holders were still unequally favored by the non pro rata indemnification they received in relation to Brazilian investors who suffered the same damages. This is because, as I now turn to, in both the Aracruz and Sadia cases, the legal actions available in Brazil did not allow for any direct financial recovery on behalf of Brazilian investors. Even if one argues that this legal flaw was previously known to the Sadia and Aracruz Brazilian investors, who allegedly discounted the securities price, the cross-listing decision itself could have been made after their original investment, and market inefficiencies may also have taken their toll on foreign investors, as discussed in Part III below.

\section{Brazilian Private Suits}

The Sadia and Aracruz lawsuits filed in Brazil are functionally equivalent to U.S. derivative suits, not to class actions. But procedural aspects of Brazilian derivative suits differ from their U.S. counterparts. Delaware law, for example, requires that, prior to bringing the suit, the shareholder first make a demand on directors to have the corporation bring the suit itself, ${ }^{60}$ or plead that such a demand would be futile. ${ }^{61}$

In contrast, the Brazilian derivative suit must be approved by a resolution in a general meeting of shareholders. The shareholders decide whether the corporation will bring a civil liability action against an officer or director for losses caused to the corporation's property. ${ }^{62}$ If the shareholders approve

60 Model Bus. Corp. Act ch. 7D (requiring prior written demand with notice upon the directors); DE Court of Chancery Rule 23.1 (requiring the plaintiff shareholder to first make a demand on the board to sue a director/officer. Directors have the opportunity to dismiss the suit as not in the best interests of the corporation. If the board refuses, the shareholder can bring a derivative suit).

61 The shareholder has to demonstrate a reasonable doubt that the board would independently make a fair decision as to litigating against its directors or managers. Aronson v. Lewis, 473 A.2d 805, 810 (Del. 1984). Even if demand is shown to be futile, the board can constitute a special independent litigation committee that may still decide not to pursue charges. Robert B. Thomson \& Randall S. Thomas, The Public and Private Faces of Derivative Suits, 57 Vand. L. Rev. 1747, 1758-59 (2004).

62 Lei No. 6.404, de 15 dezembro de 1976, D.O.U. 1.12.1976, art. $159 \S 1^{\circ}$ (Braz.). 
the suit but the company fails to bring the action within three months, any shareholder may file the lawsuit herself on behalf of the company ${ }^{63}$ If the shareholders do not approve the suit, a shareholder owning five percent of the total capital may still bring the action on behalf of the company. ${ }^{64}$ Any financial recovery resulting from the suit will belong to the corporation, and the company shall reimburse all the expenses incurred by the shareholder who eventually filed the action. ${ }^{65}$

Brazilian shareholders of Sadia and Aracruz approved in their general meetings liability suits solely against the former CFOs of their companies, seeking to hold them liable for the financial losses they caused to the companies. Plaintiff Sadia filed a lawsuit in São Paulo against former CFO Adriano Ferreira, while plaintiff Aracruz filed against CFO Isaac Zagury in Rio de Janeiro. These cities were the defendants' respective domiciles.

Sadia claimed that defendant Ferreira had violated his duties of care and loyalty by engaging in derivative transactions that breached the company's financial policies, including their contracting limits and risk exposure ceilings. ${ }^{66}$ Sadia also alleged he withheld information on the transactions from the board of directors and its committees. It claimed causality between his actions and omissions and the company's financial losses, and requested indemnification against all the losses suffered. Although the Aracruz lawsuit proceeded in secrecy of justice, ${ }^{67}$ it is very likely that its legal arguments were generally

\section{$63 I d . \S 3^{\circ}$.}

$64 I d . \S 4^{\circ}$.

$65 I d . \S 5^{\circ}$. The rationale of the Brazilian derivative suit reflects the model of concentration of corporate ownership that prevails in most Brazilian corporations. See Gorga, supra note 8; Gorga, supra note 6. It places decision rights in the hands of the shareholders at their general meeting, which usually enjoys a high participation rate. Shareholders with large blocks of shares are properly incentivized to participate, and minority shareholders are protected by the ability to file suit even if a controlling shareholder opposes the filing decision in the general meeting.

66 Because corporate and securities laws are federal laws in Brazil, the arguments were considerably different than the ones advanced in the securities class actions in the United States. See Gorga, supra note 13, Section IV.2.

67 Código de Processo Civil [C.P.C.] [Brazilian Civil Procedure Code] art. 155 I (Braz.) exceptionally allows lawsuits to be processed in a confidential manner whenever doing so serves the "public interest." Judges have allowed an increasing number of lawsuits to proceed this way, generating asymmetries of information in corporate litigation. I further discuss and criticize this issue in Gorga, supra note 13, Section IV.3.1. 
similar to the ones raised in the Sadia suit. ${ }^{68}$

The São Paulo Justice Court upheld a legal argument raised by defendant Ferreira's motion to dismiss. ${ }^{69}$ Ferreira relied on the fact that a subsequent meeting of Sadia's shareholders approved without reservations the financial statements revealing the company's losses. This fact, according to defendant's counsel, invoked the application of an exoneration provision available in article $134 \S 3^{\circ}$ of Brazilian Corporations Law. ${ }^{70}$ The São Paulo appeal court upheld this argument and extinguished the suit for lack of legal basis, without judging its merits. ${ }^{71}$ After several appeals, the Superior Tribunal of Justice, the highest Brazilian court for private law, affirmed. ${ }^{72}$ As a consequence, Sadia lost its case and received no indemnification. Further, because Brazil adopts the "loser pays" system, Sadia also had to bear the expenses related to the suit.

The Aracruz lawsuit yielded a different outcome. Because the approvals of Aracruz's financial statements in Aracruz's shareholder meetings were performed "with reservations," 73 defendant Zagury could not rely on the legal exonerating provision of article $134 \S 3^{\circ}$. Instead, the lawsuit proceeded and both parties agreed to settle the case for a payment of $\mathrm{R} \$ 1,500,000$ to Aracruz by defendant Zagury. ${ }^{74}$ Therefore the company recovered a minimal amount of its losses, but Aracruz shareholders in Brazil were not entitled to any direct financial recovery. This is because the financial results of a Brazilian

68 The costs of this suit were borne by all Sadia investors, including U.S. investors. However, it is important to note that if the suit resulted in any financial recovery, that recovery would belong to the company, and therefore to all Sadia's securities holders, including Brazilian and U.S. ones. See the discussion regarding the Aracruz derivative suit outcome infra note 73-76 and accompanying text.

69 Gorga, supra note 13, Section IV.2 (conducting a detailed analysis of the suit).

70 Lei No. 6.404, de 15 dezembro de 1976, D.O.U. 1.12.1976, art. 134 § $3^{\circ}$ (Braz.) ("The approval, without reservations, of the financial statements and accounts shall exempt the officers and members of the statutory audit committee from liability ....”).

71 T.J.S.P. Agravo de Instrumento No. 990.09.362587-3. Relator: Des. Enio Zulani, DiÁRIO de JustiçA [D.J.] 27.09.2010, 792 (Braz.).

72 S.T.J. ResP. No. 1.313.725 — SP (2011/0286947-4). Relator: Min. Ricardo Villas Bôas Cueva, Dí́rio de JustiçA Eletrônico [D.J.E.] 19.02.2013 (Braz.).

73 Ata da Assembleia Geral Ordinária da Aracruz S.A. [Minutes of the Annual General Meeting of Aracruz S.A.], Comissão de VAlores Mobiliários [Securities And Exchange Commission] (Apr. 30, 2009), http://siteempresas.bovespa.com. $\mathrm{br} /$ consbov/ArquivoComCabecalho.asp $?$ motivo $=\&$ protocolo $=201106 \&$ funcao $=$ visualizar $\&$ Site $=C$.

74 The corresponding value was $\$ 710,193.60$ on December 3, 2012 (the day the settlement was approved or "data de homologação da transação"), according to the Brazilian Central Bank conversion rate. 
derivative suit, similarly to its U.S. counterpart, belong to the company and not to its shareholders.

One could argue that the Brazilian shareholders could then have indirectly benefited from the company's derivative suit settlement if the value of their shares rose as a consequence of the company's cash recovery. ${ }^{75}$ However, precisely because this financial gain belongs to company, all the company's securities holders could potentially benefit from securities price appreciation. The company's capital recovery in a derivative suit is ultimately property of all Aracruz investors, both Brazilian shareholders and U.S. ADR holders. Hence, the Brazilian private enforcement action does not raise the same wealth distribution concerns that the U.S. securities class actions do. On the contrary, the Brazilian response produces an additional wealth transfer from Brazilian shareholders who directly suffered the securities fraud to other securities holders. ${ }^{76}$

\section{Comparison Between the American and the Brazilian Private Suits}

Having described the final outcomes of the private actions filed in connection with Sadia and Aracruz's financial losses in the United States and Brazil, I will now discuss why they were so contrasting. Considering the same factual background and alleged wrongdoing described above, one important question is why the type of legal lawsuits differed in both jurisdictions. As I discussed, private litigation in both cases relied upon securities class actions in the United States and derivative actions in Brazil.

75 However, the available literature has not been able to document positive share value reactions in response to litigation outcomes. See Adam C. Pritchard \& Stephen P. Ferris, Stock Price Reactions to Securities Fraud Class Actions Under the Private Securities Litigation Reform Act (Mich. Law \& Econ., Research Paper No. 01-009, 2001), available at http://ssrn.com/abstract=288216 (finding a high negative price reaction to the revelation of potential fraud, and a smaller statistically significant negative reaction to the filing of a lawsuit. The authors however do not find significant price reaction to the outcome of litigation); see also Paul A. Griffin, Joseph A. Grundfest \& Michael A. Perino, Stock Price Response to News of Securities Fraud Litigation: An Analysis of Sequential and Conditional Information, 40 ABacus 21 (2004).

76 On another level, one can argue the following distributional effect: wealth is transferred from Brazilian trading shareholders, who directly suffered capital losses due the acute drop of their share value in the secondary market as a reaction to the securities fraud revelation, to non-trading investors who may have suffered less of a direct impact on their investment value due to the fraud. 
I start with the Brazilian lawsuits. Although Brazilian law provides for a general class action framework to remedy losses to securities holders associated with capital markets transactions since $1989,{ }^{77}$ there are many drawbacks hindering their use in practice. The existing framework prohibits contingency fees agreements by which plaintiffs' attorneys could fund the class action litigation with the expectation of receiving a percentage of the recovery eventually obtained through either settlement or judgment. ${ }^{78}$ Therefore, private parties lack the economic incentives to bring claims. Public prosecutors also lack incentives and the expertise to bring these actions. ${ }^{79}$ The Brazilian securities law does not have a well-developed doctrine or case law analogous to the United States' "fraud on the market" theory, so as to allow recovery of damages in a private securities fraud action. ${ }^{80}$ Other problems include procedural rules that preclude settlement agreements binding absent members, and a lack of discovery provisions for fact investigation. ${ }^{81}$ The difficulty of

77 The closer functional equivalent to the U.S. private class action is the Brazilian "public civil action," enabled by a statute from 1985. See Lei No. 7.347, de 24 de Julho de 1985, D.O.U. de 25.7.1985 (Braz.). This action is called "public" because it was primarily conceived to be filed by public prosecutors. See id. art. $5^{\circ}$, I. Only in 1989 a new statute enabled public civil action claims based on losses caused to securities holders. See Lei No. 7.913, de 7 de Dezembro de 1989, D.O.U. de 11.12.1989, art. $1^{\text {o }}$ (Braz.).

78 Keith S. Rosenn, Civil Procedure in Brazil, 34 Aм. J. Comp. L. 487, 519 (1986) ("Fee arrangements totally contingent upon success on litigation are not used and would be regarded as a violation of the attorney's ethical duty to charge a fair amount his services.").

79 Associations are also granted standing to sue under certain conditions, but individual class members are not. See Lei No. 7.347/85 art. $5^{\circ}, \mathrm{V}$.

80 See generally Halliburton Co. v. Erica P. John Fund, Inc., No. 13-317, 2014 WL 2807181 (June 23, 2014); Basic Inc. v. Levinson, 485 U.S. 224 (1988) (articulating fraud-on-the-market theory); Merrit Fox, Securities Class Actions Against Foreign Issuers, 64 StAn. L. REv. 1173, 1189-90 (2012) ("The fraudon-the-market presumption of reliance, by making class actions possible, made practical for the first time the pursuit of the claims of ordinary portfolio investors who suffer losses from share transactions at prices unfavorably influenced by issuer misstatements.").

81 See Gorga, supra note 13, at 52-55; see also Antonio Gidi, Class Actions in Brazil - A Model for Civil Law Countries, 51 Aм. J. Comp. L. 311, 341-45 (2003) (discussing the shortcomings of Brazilian class actions); Antonio Gidi, The Recognition of U.S. Class Action Judgments Abroad: The Case of Latin America, 37 BRook. J. InT'L L. 893, 918-19 (2012) (focusing on the settlement legal problems) [hereinafter Gidi, Recognition]; Érica Gorga \& Michael Halberstam, Litigation Discovery \& Corporate Governance: The Missing Story About "The 
class actions, combined with the strategy that controlling shareholders took to make CFOs scapegoats for the firms' financial losses, explains the filing of derivative suits in Brazil. ${ }^{82}$

Turning to the U.S. private lawsuits, these could, in theory, have been formulated as class actions or as derivative suits. But derivative claims involve substantial procedural hurdles ${ }^{83}$ and judicial decisions are difficult to enforce internationally against foreign directors and managers residing in Brazil with no assets in the United States. These drawbacks are circumvented in securities class actions in which the corporation itself is the defendant. ${ }^{84}$

Given the developed class action infrastructure in the United States and its severely flawed counterpart in Brazil, another relevant question is why Brazilian shareholders were not included as plaintiffs in the U.S. securities class actions against Sadia and Aracruz. The decision to sue and which individuals to include in a class action are made by U.S. plaintiffs' lawyers based on economic considerations. A plaintiff's lawyer will only file and fund a class action if the expected gains from the suit outweigh the expected costs of litigation. ${ }^{85}$ In performing this calculus, lawyers consider the optimal size for the class: additional class members should be included if the marginal gain from doing so is greater than its marginal costs. ${ }^{86}$

The costs of including foreign citizens in a U.S. class action, even before Morrison, which will be discussed in Part II below, were not trivial. Costs included deposing class representatives, managing discovery when most of the evidence and parties were outside the United States, effecting notice

Genius of American Corporate Law,” 63 EMORY L.J. 1383 (2014) (discussing the lack of discovery in civil law jurisdictions and its consequences for corporate litigation).

82 For a discussion of controlling shareholders' interests and incentives, see Gorga, supra note 13 , at 52 .

83 Kenneth B. Davis, Jr., The Forgotten Derivative Suit, 61 VAnd. L. Rev. 387, 400 (2008) ("Thus, over a period of less than ten years, the demand requirement was recast to pose a higher hurdle to derivative suits alleging directors' breach of duty."); see also Thompson \& Thomas, supra note 61 at 1762 ("The relative popularity of class actions could stem from the fact that these plaintiffs avoid some of the difficulties arising from the demand requirements and other procedural provisions that apply to derivative suits."); supra notes 60-61 and accompanying text.

84 Gorga, supra note 13, at 51-52.

85 Linda Sandstrom Simard \& Jay Tidmarsh, Foreign Citizens in Transnational Class Actions, 97 Cornell L. Rev. 87, 96 (2011).

86 Id. at 101; see also David Betson \& Jay Tidmarsh, Optimal Class Size, Opt-Out Rights, and "Indivisible” Remedies, 79 Geo. WASH. L. REv. 542, 554-68 (2011). 
for class members residing in foreign jurisdictions, and calculating and delivering remedies for foreign citizens. For a judgment or settlement to be fully enforceable in the jurisdiction of foreign class members, the order of the American court must be recognized in foreign courts. ${ }^{87}$ Because there was no precedent of a suit against a Brazilian corporation in a U.S. securities class action, doubts existed as to whether American courts would certify Brazilian shareholders. Scholars opine that Brazilian courts would not recognize an American decision in a class action, making it likely that Brazilian shareholders would be excluded from U.S. class actions. ${ }^{88}$ Above all, doubts may have existed regarding the legal basis under the pre-Morrison conduct test to assert claims on the foreign plaintiffs' behalf. ${ }^{89}$ Therefore, for all the reasons given above, it is very likely that U.S. lawyers found it too risky to include the Sadia and Aracruz Brazilian shareholders in their class actions. Having discussed the rationale underlying the strategic decisions of plaintiffs in the U.S. and Brazilian lawsuits, I now turn to the effects of Morrison on the complaints of foreign shareholders in the United States.

87 See Gidi, Recognition, supra note 81, at 895 (2012) ("The question therefore remains whether the class action defendant will be able to assert res judicata against the foreign absent class members in a subsequent proceeding, or whether foreign absent class members will be able to bring their own individual or class action lawsuits abroad.").

$88 I d$. at 955 ("[A] judgment or court-approved settlement in a U.S. class action for damages would not be recognized or enforced in Latin American countries."). See Matthew H. Jasilli, Note, A Rat Res? Questioning the Value of Res Judicata in Rule 23(b)(3) Superiority Inquiries for Foreign Cubed Class Action Securities Litigations, 48 Colum. J. TRANSNAT'L L. 114, 121-31 (2009) (discussing standards adopted by U.S. Courts for assessing "lack of superiority" and denying class certification); Marco Ventoruzzo, Like Moths to Flame? International Securities Litigation After Morrison: Correcting the Supreme Court's "Transactional Test," 52 VA. J. INT'L L. 405, 415 (2012):

The more profound and significant the differences between the home jurisdiction and the United States, the more a foreign plaintiff might find it attractive to sue in the United States. These profound differences also reduce the deference that the U.S. decision or settlement might receive abroad, thus negatively affecting the likelihood of its enforcement and the scope of claim preclusion. This possibility, in turn, affects the "superiority" requirement of a class action that includes foreign plaintiffs, leading American judges to exclude foreign claimants from the class altogether.

89 See Bersch v. Drexel Firestone, Inc., 519 F.2d 974, 987-88 (2d Cir. 1975) (stating that only acts taken within the United States could be used to sustain foreign purchase claims). I thank George T. Conway III for making this point. 
Having discussed the rationale underlying the strategic decisions of plaintiffs in the U.S. and Brazilian lawsuits, I now turn to the effects of Morrison on the complaints of foreign shareholders in the United States.

\section{Morrison and Current Proposals for Fixing Transnational Securities Litigation}

In 2010, the U.S. Supreme Court dramatically changed the rationale of securities litigation involving foreign issuers in the United States. Before Morrison, U.S. courts had jurisdiction over cases based on conduct taking place in the United States and whose effect was felt within the United States. These standards had been criticized due to their lack of predictability and uncertainty in defining the extraterritorial limits of securities litigation..$^{90}$ In many cases, courts relying on these tests extended the extraterritorial reach of U.S. securities laws. ${ }^{91}$ Hence, foreign firms at least faced a significant litigation risk in the United States in connection with the trading of their securities in foreign markets in f-cubed claims. ${ }^{92}$

Morrison announced a new "transactional test" by which the courts will assess the geographic reach of U.S. securities fraud laws. In order to determine the applicability of section 10(b) of the Securities Exchange Act, ${ }^{93}$

90 See, e.g., Buxbaum, supra note 25, at 67; Choi \& Silberman, supra note 25, at 467 ("[M] uch uncertainty surrounds the consideration of extraterritorial issues within securities class action lawsuits. The individual doctrines applied within the courts - such as the conduct and effects tests — are often ambiguous and difficult to predict."); Guseva, supra note 27, at 433 (reviewing seventy-five cases against foreign private issuers between 2001 and 2011 and concluding that there is "a significant variation in court reasoning, entailing uncertainty with respect to the final disposition of cases").

91 See, e.g., Cont'l Grain (Austl.) Pty. Ltd. v. Pac. Oilseeds, Inc., 592 F.2d 409, 411 (8th Cir. 1979); see also Buxbaum, supra note 25 (discussing the case-law); Guseva, supra note 27.

92 Cont'l Grain, 592 F.2d 409; Buxbaum, supra note 25; Guseva, supra note 27. The risk was higher for firms of specific jurisdictions that would more likely recognize an U.S. judgment. See supra note 88 and accompanying text.

93 Securities Exchange Act of 1934, § 10(b), 48 Stat. 891 (codified as amended at 15 U.S.C. $\S 78 \mathrm{j}(\mathrm{b})(2006)$ ) (making it unlawful "[t]o use or employ, in connection with the purchase or sale of any security registered on a national securities exchange or any security not so registered ... any manipulative or deceptive device or contrivance in contravention of such rules and regulations as the Commission may prescribe"). See generally Reuveni, supra note 25, at 1111-17 (analyzing the legislative purpose of the 1934 Act and concluding that 
the transactional test asks "whether the purchase or sale [1] involves a security listed on a domestic exchange, or [2] is made in the United States." 94 The Supreme Court concluded that section 10(b) applies to fraud in connection with the "purchase or sale of a security listed on an American stock exchange, and the purchase or sale of any other security in the United States."

Plaintiffs in Morrison included (a) foreign investors who purchased shares on the Australian Stock Exchange ("f-cubed plaintiffs"); and (b) Robert Morrison, who purchased ADRs on the New York Stock Exchange. Robert Morrison's ADR claim was dismissed for failure to allege pecuniary damage, ${ }^{96}$ thus precluding an analysis of whether the over-the-counter (OTC) ADRs in question would fall under U.S. jurisdiction under the court's new transactional test. ${ }^{97}$ The court's decision, then, was restricted to an analysis of the f-cubed claims. While Morrison was successful in creating a bright-line test aimed at enhancing consistency in the application of U.S. law, ${ }^{98}$ the decision left several questions unanswered..$^{99}$ Chief among these was the question how unsponsored ADRs that trade in the OTC market should be treated by courts. ${ }^{100}$

"Congress was concerned with American investors and markets" and "intended for administrative agencies, rather than private litigants, to enforce securities laws" when foreign issuers harmed them).

94 Morrison v. Nat'l Austl. Bank Ltd., 130 S. Ct. 2869, 2886 (2010).

95 Id. at 2888.

96 In re Nat'l Austl. Bank Sec., No. 03 Civ.6537BSJ, 2006 WL 3844465, at*8 (S.D.N.Y. Oct. 25, 2006).

97 Grant Swanson, Note, A Comparative Law Analysis of Private Securities Litigation in the Wake of Morrison v. National Australia Bank, 87 CHI.-Kent L. Rev. 965, 981 (2012) ("Had Morrison remained in the case, it is almost certain that Justices Stevens and Breyer, the concurring Justices, would have decided that he was entitled to bring his suit in the United States because he purchased his ADR on an American stock exchange."). However, this lack of an affirmative position has generated discrepant opinions in certain courts. See infra note 129 (pointing out the Societé Générale decision).

98 Morrison, 130 S. Ct. at 2880-81.

99 Daniel Hemel, Comment, Issuer Choice After Morrison, 28 YALE J. ON REG. 471, 471-73 (2011) (noting that questions have arisen regarding what it means for a purchase or a sale to be "made in the United States," and regarding the interpretation of Justice Scalia's "use of the logical disjunctive 'or"').

100 Joshua L. Boehm, Private Securities Fraud Litigation After Morrison v. National Australia Bank: Reconsidering a Reliance-Based Approach to Extraterritoriality, 53 Harv. InT'L L.J. 502, 522 (2012); Hannah L. Buxbaum, Remedies for Foreign Investors under U.S. Federal Securities Law, 75 Law \& Contemp. Probs. 161, 165 (2012) (referring to confusion in the treatment of ADRs). 
According to the prevailing view of the Morrison test, section 10(b) will not apply to foreign transactions even if they involve the underlying securities of a sponsored ADR listed on a U.S. domestic exchange. ${ }^{101}$ For this reason, the Morrison decision potentially undermines the supposedly legal "bonding" that foreign companies achieve by cross-listing their securities in the United States.

The bonding hypothesis holds that shares of cross-listed companies in the United States are of greater value than those of non-cross-listed companies. ${ }^{102}$ Traditionally the literature has posited that the positive value of the bonding effect was not restricted to securities traded in the U.S. markets, but also extended to the securities of U.S. cross-listed firms traded on foreign exchanges. Evidence has indeed shown that listing in the United States boosted prices for a company's securities in its home-country. ${ }^{103}$ This phenomenon made cross-listing an attractive option for foreign firms. By listing just a portion of its securities in the United States, a firm could realize benefits for all its securities, therefore achieving positive externalities and returns higher than the costs of the U.S. listing.

One factor driving the bonding premium was investor ability to "exercise effective and low-cost legal remedies, such as class actions ... that are simply not available in the firm's home jurisdiction." 104 Yet Morrison, by denying

101 See, e.g., Richard Painter, Douglas Dunham \& Ellen Quackenbos, When Courts and Congress Don't Say What They Mean: Initial Reactions to Morrison v. National Australia Bank and to the Extraterritorial Jurisdiction Provisions of the Dodd-Frank Act, 20 MinN. J. INT'L L. 1, 11 (2011):

Many companies have ADRs trading in the United States. It cannot be possibly the case that the Supreme Court intended Section 10(b) to apply not only to the ADR itself but also to a foreign purchase of the underlying stock on a foreign exchange simply because the underlying shares are registered in the United States to enable the company to issue the ADR.

See also infra note 129.

102 Craig Doidge, G. Andrew Karolyi \& René M. Stulz, Why Are Foreign Firms Listed in the U.S. Worth More?, 71 J. Fin. ECON. 205, 205 (2004) ("[F]oreign companies with shares cross-listed in the U.S. had Tobin's q ratios that were $16.5 \%$ higher than the q ratios of non-cross-listed firms from the same country."); see also Craig Doidge, G. Andrew Karolyi \& René M. Stulz, Has New York Become Less Competitive than London in Global Markets? Evaluating Foreign Listing Choices Over Times, 91 J. Fin. Econ. 253 (2009).

103 Craig Doidge, U.S. Cross-Listings and the Private Benefits of Control: Evidence from Dual-Class Firms, 72 J. Fin. ECON. 519, 521 (2004) ("[D]espite the fact that most dual-class firms cross-list only the low-voting share class in the U.S., both share classes benefit from the announcement of a U.S. listing.").

104 John C. Coffee, Jr., Racing Towards the Top?: The Impact of Cross-Listings and Stock Market Competition on International Corporate Governance, 102 CoLuM. 
this ability to foreign investors who acquired securities in a foreign exchange, has undermined the legal basis of bonding and thus threatened the bonding premium. ${ }^{105}$

The U.S. District Court for the Southern District of New York, for example, has interpreted Morrison in this restrictive way, collapsing the two prongs of Morrison into one. The court has focused only on where the transaction occurs, holding that section 10 (b) does not apply to any transactions in a foreign market. In this way it has neglected the inquiry as to whether the security at issue is listed on a U.S. exchange. ${ }^{106}$ To restore the bonding premium to at least some particular types of cross-listed firms, commentators such as Daniel Hemel have proposed that the court revise its stand in future decisions to take the position that section 10(b) does apply to foreign transactions involving shares of firms that cross-list their common stock for trading on a U.S. exchange. With such a holding, foreign firms would be able to engage in a credible bonding commitment by adhering to U.S. law by means of a de facto issuer choice regime. ${ }^{107}$

L. Rev. 1757, 1780 (2002); G. Andrew Karolyi, Corporate Governance, Agency Problems and International Cross-Listings: A Defense of the Bonding Hypothesis, 13 Emerging Мкт. Rev. 516, 524 (2012) (reviewing the extant literature on legal bonding, but concluding that "a proper verdict about the bonding hypothesis, especially of its purer 'legal' form, has not yet been fully rendered. I think a more complete understanding of the enforcement mechanisms around the world, their financial needs as inputs and the full scope of legal outcomes is still needed").

105 To be sure, the legal bonding hypothesis has been questioned as the rationale for cross-listing - even before Morrison. See, e.g., Amir N. Licht, Cross-Listing and Corporate Governance: Bonding or Avoiding?, 4 CHI. J. INT'L L. 141 (2003); Natalya Shnitser, A Free Pass for Foreign Firms? An Assessment of SEC and Private Enforcement Against Foreign Issuers, 119 Y ALE L.J. 1638 (2010); Jordan Siegel, Can Foreign Firms Bond Themselves Effectively by Renting U.S. Securities Laws?, 75 J. Fin. Econ. 319 (2005); see also infra note 124 (discussing available studies on the effects of Morrison). An alternative hypothesis is that bonding can result from reputational effects, as advanced by a related body of literature. See Gilberto Loureiro, The Reputation of Underwriters: A Test of the Bonding Hypothesis, 16 J. CoRP. FIN. 516 (2010) (arguing that reputational bonding could also affect share prices apart from the legal bonding discussed above); see also Hemel, supra note 99, at 480 n.58; Karolyi, supra note 104, at 523-25.

106 See Hemel, supra note 99, at 473-74 (reviewing the Court's decisions).

107 Id. at $487-88$. 
In the same vein, Vincent Chiappini has reviewed how courts have applied the Morrison test to ADR transactions. ${ }^{108} \mathrm{He}$ also proposes a more expansive approach, arguing that an investor's purchase of sponsored ADR programs (Level III, Level II, Level I, and Rule 144A ${ }^{109}$ ) should meet one of Morrison's prongs and therefore be subject to lawsuits under section 10(b). In contrast, unsponsored ADR programs should not be subject to U.S. antifraud claims. ${ }^{110}$ Therefore, under this approach sponsored ADR programs would allow legal bonding.

The implications of Morrison's "transactional test" go beyond f-cubed claims. Some commentators have focused on how it has affected fraud suits against foreign issuers brought by American investors who purchased securities abroad ("f-squared complaints"), criticizing that Morrison also bars American investors from seeking remedies under U.S. securities laws. ${ }^{111}$ If true, in this view, such a bar would mean a "shocking loss" of investor legal protection. ${ }^{112}$ U.S. courts have in fact adopted this interpretation, thus excluding American investors who acquired securities overseas from U.S. securities class actions. ${ }^{113}$

108 Vincent M. Chiappini, Note, How American Are American Depositary Receipts? ADRs, Rule 10b-5 Suits, and Morrison v. National Australia Bank, 52 B.C. L. REV. 1795 (2011).

109 See generally U.S. Sec. \& Exchange Comm'n, Investor Alerts and Bulletins: AmERICAN Depositary ReCEIPTS (2012), available at http://www.sec.gov/investor/ alerts/adr-bulletin.pdf (explaining the three levels of ADRs).

110 See Chiappini, supra note 108, at 1832.

111 E.g., Nidhi M. Geevarghese, Note, A Shocking Loss of Investor Protection: The Implications of Morrison v. National Australia Bank, 6 BRooK. J. CorP. Fin. \& CoM. L. 235 (2011). Supreme Court Justices Stevens and Ginsburg concurred in the judgment but disagreed with the Court's reasoning. Morrison v. Nat'l Austl. Bank Ltd., 130 S. Ct. 2869, 2888 (2010) (Stevens, J., concurring):

Imagine . . a an American investor who buys shares in a company listed only on an overseas exchange. That company has a major American subsidiary with executives based in New York City; and it was in New York City that the executives masterminded and implemented a massive deception which artificially inflated the stock price - and which will, upon its disclosure, cause the price to plummet .... [The] investors would, under the Court's new test, be barred from seeking relief under $\S 10(b)$.

See also Morrison, 130 S. Ct. at 2895 (showing how in this particular case the "American investor" is defined by her nationality, and not by the location where she acquired securities).

112 Geevarghese, supra note 111.

113 See, e.g., In re UBS Sec. Litig., No. 07-11225, 2011 WL 4059356, at *5-8 (S.D.N.Y. Sept. 13, 2011); In re Royal Bank of Scotland Grp. PLC Sec. Litig., 765 F. Supp. 2d 327, 336 (S.D.N.Y. 2011); In re Vivendi Universal, S.A. Sec. 
Commentators such as Nidhi Geevarghese have since proposed that Congress pass legislation to tackle these judicial holdings, and restore the protective rights of American investors for reasons of international comity and fairness. ${ }^{114}$ Dona Muir, Junhai Liu and Haiyan Xu provide support for this proposal with their analysis of class action procedures in China, concluding that legal protections against securities fraud for investors who acquired shares from Chinese issuers are insufficient. ${ }^{115}$

Others support a return to pre-Morrison standards, albeit with a more focused approach. Marco Ventoruzzo has proposed a "new effects test" that aims to protect American investors and resolve the ambiguities created by Morrison and the pre-Morrison conduct-effects tests. Under Ventoruzzo's proposal, U.S. court jurisdiction is limited to those cases in which the United States has a substantial interest because of effects produced in its domestic markets. ${ }^{116}$ In another proposal, Joshua Boehm recommends that Congress reinstate the conducts-effect test while imposing a reliance requirement on foreign transactions. ${ }^{117}$

Linda Simard and Jay Tidmarsh have argued that courts should not exclude foreign citizens from class membership solely because their country does not recognize an American class judgment or settlement. Instead, they have proposed that courts include the claims of individual foreign citizens if those claims are not worth pursuing individually, while excluding those that are. According to the authors, this proposal mitigates the risk that class members will re-litigate in foreign forums, and in this way provides a more thorough

Litig., 2011 U.S. Dist. LEXIS 17514 (S.D.N.Y. Feb. 17, 2011) (dismissing the fraud claims by U.S. purchasers of Vivendi shares on foreign exchanges); Cornwell v. Credit Suisse Grp., 729 F. Supp. 2d 620, 623-27 (S.D.N.Y. 2010); Plumbers' Union Local No. 12 v. Swiss Reinsurance Co., 753 F. Supp. 2d 166, 178 (S.D.N.Y. 2010); Elliott Assocs. v. Porsche Auto. Holding SE, 759 F. Supp. 2d 469, 476 (S.D.N.Y. 2010); In re Alstom SA Sec. Litig., 741 F. Supp. 2d 469, 471 (S.D.N.Y. 2010).

114 Geevarghese, supra note 111, at 260 ("Such an approach will return robust investor protection measures to Americans investing in securities abroad, balance issues of international comity and fairness, and hopefully spur the development of stronger investor protections and complementary group litigation procedures overseas.").

115 Dona M. Muir, Junhai Liu \& Haiyan Xu, The Future of Securities Class Actions Against Foreign Companies: China and Comity Concerns, 46 U. MicH. J.L. ReForm 1315 (2013).

116 Ventoruzzo, supra note 88, at 408-09.

117 Boehm, supra note 100, at 542. 
decision rationale than the standard misplaced consensus that foreign class members will inevitably sue in their home country. ${ }^{118}$

All this academic debate surveyed so far has largely neglected one key issue which this Article seeks to explore: the transfer of wealth from foreign to U.S. investors, and reform proposals addressing it. The policy-making arena has also sidestepped this distributional problem, even if regulators have not fully supported the Morrison decision and its policy ramifications for the U.S. markets. The controversy has brought about contrasting developments by the legislative branch.

Congress immediately responded to the Supreme Court's decision by affording extraterritorial jurisdiction to district courts in actions involving violations of antifraud provisions brought by the Securities and Exchange Commission (SEC) and the Department of Justice. ${ }^{119}$ Many commentators, however, have noted that such a reform will not make any practical difference because, as Justice Scalia argued in Morrison, a statute must make "a clear statement of extraterritorial effect" in order to produce extraterritorial effects; ${ }^{120}$ and the Dodd-Frank reform has failed to do so as it merely references jurisdiction, but not the power of courts to apply the law to particular facts. ${ }^{121}$

With respect to private actions under section 10(b), section 929Y of the Dodd-Frank Act required that the SEC conduct a study to determine the desirability of extending extraterritorial private rights of actions under the antifraud provisions. This study has now been released by the SEC. ${ }^{122}$ In its analysis of "the economic consequences of a cross-border extension of a section 10(b) private right of action in transnational securities," the SEC

118 Simard \& Tidmarsh, supra note 85, at 89-90.

119 Dodd-Frank Wall Street Reform and Consumer Protection Act of 2010, Pub, L. No.111-203, § 929P(b)(2), 124 Stat. 1864 (2010). This authority is granted if the fraud involves conduct within the United States, that is "a significant step in furtherance of the violation, even if the securities transaction occurs outside the United States and involves only foreign investors," or has a substantial effect within the United States. Id.

120 Morrison v. Nat'l Austl. Bank Ltd., 130 S. Ct. 2869, 2883 (2010).

121 See generally Painter, Dunham \& Quackenbos, supra note 101, at 4, 25 (arguing that Congress should "enact a legislative fix before the government and private parties are burdened by litigation"); see also Meny Elgadeh, Note, Morrison v. National Australia Bank: Life After Dodd-Frank, 16 FordhAm J. CorP. \& Fin. L. 573, 593-97 (2011) (articulating this argument in detail).

122 See U.S. Sec. \& Exchange Comm'n, supra note 30 (reporting excerpts of numerous public comments delivered by private and public parties, including regulators, which did not seem to have raised any consideration on distributional issues per se). 
opined that "[c]onsidering both the existing economic research and the results of our analysis, we are unable to document evidence of either economic costs or economic benefits that could be clearly and directly linked to extending a private right of action." ${ }^{23}$ The SEC cited mixed economic empirical evidence that is largely inconclusive. ${ }^{124}$

One of the SEC's proposals includes granting a section 10(b) right of private action for the purchase or sale of any security of the same class of securities registered in the United States, irrespective of the actual location of the transaction. ${ }^{125}$ Although the SEC's analysis did not refer to the issue of cross-border wealth transfers between groups of investors, which is the focus of this Article, this proposal would certainly minimize Morrison's distributional effects - discussed further in the next Part.

\section{The Sadia ANd Aracruz Outcomes: The "Double Circularity" Problem in Transnational Securities Litigation}

The Sadia and Aracruz cases did not involve any explicit discussion of U.S. extraterritorial jurisdiction discussed under Morrison for two basic reasons. ${ }^{126}$ First, both litigations began before the U.S. Supreme Court ruling in Morrison. ${ }^{127}$

123 Id. app. B, at B1.

124 Id. app. B, at B8. One study by Licht and others finds evidence that Morrison has positively affected the stock prices of foreign firms, which would cut against a cross-border extension of the right of private action for foreign investors. Amir N. Licht, Christopher Poliquin, Jordan I. Siegel \& Xi Li, What Makes the Bonding Stick? A Natural Experiment Involving the Supreme Court and Cross-Listed Firms (Harv. Bus. Sch. Strategy Unit, Working Paper No. 11-072, 2013), available at http://ssrn.com/abstract=1744905. But see Louis Gagnon \& G. Andrew Karolyi, Economic Consequences of the U.S. Supreme Court's Morrison v. National Australia Bank Decision for Foreign Stocks Cross-Listed in U.S. Markets (Johnson Sch. Research Paper Series No. 50-2011, 2012), available at http://ssrn.com/abstract=1961178 (finding a thirty-seven basis point increase in the price deviation between cross-listed shares trading in the United States and the underlying home market shares at the time that Morrison was decided, which provides evidence that the market values positively the U.S. liability cause of action, data which supports a cross-border extension).

125 U.S. SeC. \& Exchange Comm'n, supra note 30, at 64.

126 None of the documents available in the Sadia and Aracruz case dockets in Bloomberg Law filed by the parties or judicial orders contain any mention of Morrison.

127 The Sadia and Aracruz litigations started respectively on November 5, 2008 
Second, the Morrison holding would not impact the plaintiffs' cause of action in either case, as the U.S. plaintiffs in both the Sadia and the Aracruz complaints were covered under the Morrison transactional test. Sadia and Aracruz listed their ADRs for trading on a U.S. exchange. Plaintiffs purchased these companies'ADRs on a U.S. exchange - the NYSE. ${ }^{128}$ And indeed, even if the Supreme Court has sidestepped the ADR issue, most Court decisions interpret jurisdiction under Morrison to include acquirers of ADRs or American Depositary Shares (ADSs) in litigating securities fraud claims against foreign firms. ${ }^{129}$

A problem would arise only if Brazilian investors were potentially included as plaintiffs in the Sadia and Aracruz class action suits. Sadia and Aracruz did not list their underlying common or preferred shares on a U.S. exchange. These shares were listed and traded in the Brazilian São Paulo Stock Exchange BM\&FBovespa. The relevant question, then, is whether Brazilian securities holders of Sadia and Aracruz pass the Morrison "transactional test" and can participate as plaintiffs under the umbrella of U.S. jurisdiction. The answer is negative.

and on November 25, 2008. The judicial orders preliminarily approving their settlements were issued on September 22, 2011 and March 14, 2013. The Morrison litigation began in 2001, but the Supreme Court decision was issued on June 24, 2010. Even if Morrison was decided during the process of the Sadia and Aracruz litigations, its impact in their settlements is unclear as it did not impact plaintiffs' claims in either of the cases. See infra notes 128-129 and accompanying text.

128 See Chiappini, supra note 108, at 1825 ("Level II and Level III ADR programs fulfill Morrison's listing prong because they are listed and traded on a U.S. exchange.").

129 See, e.g., Stackhouse v. Toyota Motor Co., No. 10-CV-0922, 2010 WL 3377409 , at *1-2 (C.D. Cal. July 16, 2010); In re Vivendi Universal, S.A. Sec. Litig., No. 02 Civ. 05571, 2011 U.S. Dist. LEXIS 17514, at*38 (S.D.N.Y. Feb. 17, 2011) ("The parties agree that Morrison has no impact on the claims of ADR purchasers since Vivendi's ADRs were listed and traded on the NYSE."'); In re Elan Corp. Sec. Litig., No. 08-Civ.-8761, 2011 WL 1442328, at*1 (S.D.N.Y. Mar. 18, 2011). But see In re Societe Generale Sec. Litig., No. 08 Civ. 2495, 2010 U.S. Dist. LEXIS 107719, at*19 (S.D.N.Y. Sept. 29, 2010) (discussing the purchase of over-the-counter ADRs and concluding that "because [t]rade in ADRs is considered to be a 'predominantly foreign securities transaction,' Section 10(b) is inapplicable"" (quoting Copeland v. Fortis, 685 F. Supp. 2d 498, 506 (S.D.N.Y. 2010)); Swanson, supra note 97, at 982 (arguing that the court applied a substantial effect rationale rejected by Morrison considering that the company had only a small percentage of its total equity in ADRs). 
Morrison expressly says that the reach of the section 10(b) antifraud regime does not extend to purchases of the issuer's underlying common stock in foreign markets. ${ }^{130}$ Therefore, under the current interpretation of Morrison, Sadia's and Aracruz's Brazilian investors - that is, investors who acquired Sadia's and Aracruz's preferred (or common) shares in Brazil — are not entitled to participate as plaintiffs in U.S. suits. ${ }^{131}$ Under this current interpretation, only foreign investors who purchase securities either through a U.S. exchange or otherwise in the United States would pass Morrison's transactional test and thus reap the benefits of U.S. securities laws. ${ }^{132}$

A simple cost-benefit analysis of the private enforcement actions in the United States and in Brazil makes evident the distributional problems posed by the current transnational litigation regime. On the one hand, while the costs of the U.S. class actions suits are borne by both foreign investors and U.S. investors, the cash recoveries produced by these suits are directly and exclusively distributed to U.S. investors who constitute the class that suffered from the securities fraud. On the other hand, the costs of the Brazilian derivative

130 The case of Brazilian investors who acquired shares of Sadia and Aracruz in Brazil would be analogous to the Australian investors who acquired common shares of National Australia Bank in the Australian Stock Exchange. The only caveat here is that in the Sadia and Aracruz cases, the ADRs were referenced on preferred (nonvoting) shares and not on common shares, as was the case in Morrison. See Morrison v. Nat'l Austl. Bank Ltd., 130 S. Ct. 2869, 2875 (2010).

131 See Irwin H. Warren \& Margarita Platkov, Further Look at Morrison: A Plain Meaning Analysis, N.Y.L.J., Nov. 2, 2010, http://www.newyorklawjournal.com/ id=1202474256238/Further-Look-at-Morrison-A-Plain-Meaning-Analysis?slret urn=20140809103539 (arguing, as counsel for the defense in two cases in which the common shares were U.S.-exchange-listed to enable an ADR listing, but not listed for trading, that "listed" and "listed for trading" are different and that Justice Scalia purposefully used "listed" to mean "listed for trading"); see also 17 C.F.R. $§ 240.3 b-1$ (2011) ("The term listed means admitted to full trading privileges ....").

132 See In re Stackhouse v. Toyota Motor Co., No. 10-0922, 2010 WL 3377409, at *1-3 (CD. Cal. July 16, 2010); Royal Bank of Scotland Grp. PLC Sec. Litig., 765 F. Supp. 2d 327, 336 (S.D.N.Y. 2011); In re Alstom SA Sec. Litig., 741 F. Supp. 2d 469, 471 (S.D.N.Y. 2010); Cornwell v. Credit Suisse Grp., 729 F. Supp. 2d 620, 627 (S.D.N.Y. 2010); Plumbers' Union Local No. 12 Pension Fund v. Swiss Reinsurance Co., 753 F. Supp. 2d 166, 177-78. (S.D.N.Y. 2010); In re Royal Bank of Scotland Grp. PLC Sec. Litig., 765 F. Supp. 2d 327, 336 (S.D.N.Y. 2011) ("The idea that a foreign company is subject to U.S. securities laws everywhere it conducts foreign transactions merely because it has 'listed' some securities in the United States is simply contrary to the spirit of Morrison."); U.S. Sec. \& Exchange Comm'n, supra note 30, at 28. 
suits are supported by Brazilian and U.S. securities holders, but their financial gain indirectly benefits both Brazilian and U.S. investors.

In this vein, there are two major problems stemming from Morrison's geographic transactional test for global securities litigation. The first concerns the different financial recoveries obtained by shareholders who hold similar securities and equivalent economic claims against the same company. As both Sadia and Aracruz demonstrated, U.S. ADR holders received cash compensation that was not paid pro rata to Brazilian shareholders. As Brazilian shareholders suffered the same harms as U.S. ADR holders, this result raises acute fairness considerations in the world of transnational securities transactions.

As discussed above, the Brazilian shareholders could have theoretically had a cause of action in the United States against both companies at the time the Sadia and Aracruz suits were filed. The failure of U.S. class action plaintiff lawyers to file that claim on behalf of Brazilian shareholders is probably explained by a cost-benefit decision. ${ }^{133}$ Morrison has aggravated this incentives problem for all claims by foreign investors by denying altogether a cause of action for shareholders who acquired securities outside the United States.

Apart from the non pro rata compensation issue, but still related to it, is a second problem. This concerns the question of who bears the cost of the capital transferred from current shareholders of the defendant corporation to a subset of equity holders who transacted in the United States or acquired securities cross-listed on a U.S. exchange. The costs of compensation also fell on Aracruz's and Sadia's general foreign investors, including simultaneously harmed foreign investors, while exclusively benefiting their American counterparts. This burden raises distributive and allocative considerations related to the efficiency of the current system of transnational securities litigation.

As Merrit Fox explains:

Extending the U.S. cause of action to U.S.-resident purchasers of the issuer's shares but not to foreign purchasers results in a non-pro rata dividend to the U.S. investors, paid for, typically, in large part by investors who are residents of the rest of the world. Unlike a traditional fraud action, any given U.S. investor is as likely to be a seller and the beneficiary of the conduct as she is to be a buyer and suffer a deprivation. If the U.S. buyers get compensation for their deprivations and foreign buyers do not, while sellers from everywhere keep their gains, there is an arbitrary transfer of wealth from foreign investors to U.S. investors. ${ }^{134}$

133 See supra notes 85-89 and accompanying text.

134 Fox, supra note 80, at 1237. 
When the company or its successor bears the expenses of a U.S. lawsuit, it uses corporate resources - which are supposed to belong to all equity holders - to pay a particular subset of U.S. equity holders. But what makes this particularly egregious is that, under Morrison, foreign shareholders who bear these expenses may have suffered the same damages as U.S. securities holders. This happens if they decided to keep their shareholding ownership instead of selling their stakes in the secondary markets. ${ }^{135}$ In this case, shareholders are supporting the costs of the company's fraudulent representation twice: first, when their shares lose value due to the wrongdoing per se; second when they bear the costs of indemnification paid exclusively to U.S. securities holders. Therefore, Morrison results in U.S. class action compensations based on a cross-border value distribution to U.S. investors to the detriment of foreign investors. The problem with these distributions of wealth is that they are hardly justified either on Pareto or Kaldor-Hicks grounds. ${ }^{136}$

In this sense, foreign shareholders face an aggravated circularity problem. ${ }^{137}$ The standard circularity problem applies to all securities holders who did not cause the fraud but did not suffer its direct losses either. These are securities holders who typically did not qualify to the class directly damaged by the fraud, since they acquired securities other than the ones that were overvalued on the stock market due to the material misrepresentations made by the company. ${ }^{138}$ The basic circularity problem thus is clearly present in transnational securities litigation to the extent that all the unharmed investors of a company bear the costs of the compensation paid to harmed U.S. investors. Yet foreign shareholders who were damaged by the same securities misrepresentations, and thus suffered equivalent financial losses, may still bear compensation costs generated by the recovery of U.S. ADR holders in addition to not

135 This strategy is likely to be undertaken by investors who do not want to fully consummate their losses, because they may expect the share price to appreciate in the future.

136 A Pareto improvement occurs when a change to a different economic allocation makes at least one individual better off without making any individual worse off. A new economic allocation is efficient under Kaldor-Hicks if the gains to individuals made better off exceed the losses of those whose position was worsened. Because Morrison makes foreign investors worse off, all transaction costs considered, it is hard to envision how the gains of American investors could be larger than foreign investors' losses, especially if one considers the multiplier effect of these losses due to the double circularity problem.

137 See Coffee, supra note 16, at 1536 n.5 (arguing that innocent shareholders support the costs of securities fraud recoveries).

138 This is the Basic presumption of "class wide reliance derived from the fraud on the market theory.” See Basic Inc. v. Levinson, 485 U.S. 224 (1988). 
being indemnified for their own first-order financial losses. For this reason, transnational securities litigation presents a differentiated "double circularity problem" for foreign investors who bought overvalued securities but could not constitute a class for the sake of recovery as a consequence of the lack of class action litigation infrastructure in their home countries. In a nutshell,

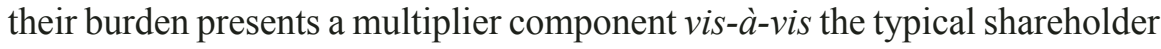
not directly affected by the fraud.

Notwithstanding, the literature has shown a bias toward the inapplicability of U.S. securities regulation to foreign issuers, alleging that such exemption would lower issuer costs for a U.S. cross-listing, therefore attracting foreign issuers with benefits of the U.S. markets. ${ }^{139}$ The literature has pointed out generic political and economic costs stemming from the extraterritorial effects of the U.S. securities regime that would damage U.S. foreign policy, multinational businesses, and ultimately American investors. ${ }^{140}$ However, considering the global allocation of costs and benefits untangled above, it is surprising that the literature has failed to distinguish the set of specific direct costs that the geographical rationale imposes on foreign securities holders. The case studies of the Brazilian corporations discussed in this Article thus shed light on the subsidization costs that foreign investors of foreign issuers bear as an intrinsic component of U.S. cross-listing under Morrison. Furthermore, these foreignbearer costs are likely to be generalized to foreign investors from all other jurisdictions that do not employ sophisticated systems of aggregate litigation that can provide direct recovery to shareholders through private enforcement. ${ }^{141}$

Although European countries have increasingly implemented new reforms to develop forms of aggregate litigation, there remain serious doubts whether these reforms will provide an effective institutional framework that fully supports collective litigation and financial recovery for collective redress. ${ }^{142}$

139 See, e.g., Elaine Buckberg \& Max Gulker, Cross-Border Shareholder Class Actions Before and After Morrison (NERA Econ. Consulting, Working Paper, 2011), available at http://ssrn.com/abstract=1973770 (arguing that Morrison diminishes litigation costs and therefore should make it easier for foreign issuers to list in the U.S.).

140 See supra note 26 and accompanying text.

141 If a foreign jurisdiction does not provide a class action system able to produce financial indemnification of its damaged shareholders, then its shareholders will generally support the costs of a financial recovery paid to American securities holders under Morrison without being compensated for their direct financial losses.

142 See generally Richard A. Nagareda, Aggregate Litigation Across the Atlantic and the Future of American Exceptionalism, 62 VAND. L. REV. 1, 6 (2009) (providing a comparative overview of recent developments in Europe regarding 
For example, the trial of alleged securities misstatements involving Deutsche Telekom was the first test of the German reform that introduced aggregate litigation in 2005. A number of procedural problems, especially the lack of effective tools for discovery in Germany, have resulted in a ruling in favor of defendants; meanwhile an equivalent parallel litigation brought by U.S. Deutsche Telekom ADS holders in New York was settled for $\$ 120,000,000$ on their behalf. ${ }^{143}$ German commentators have described the law as "a flop." 144 This German case also presents the type of double circularity problem discussed above.

In Italy, class actions were introduced in 2007, but also face a number of technical problems that include a lack of lawyers' fees and access to information, prompting commentators to conclude that "the civil procedure system must be radically reviewed in order to generate a true, effective level of private enforcement in Italy." ${ }^{\prime 15}$ In this regard, it is fair to say that virtually all foreign jurisdictions have either no mechanisms of aggregate litigation or newly-implemented and deficient mechanisms. ${ }^{146}$

aggregate litigation, but noting that "European receptiveness to new procedures for aggregate litigation, in one form or another, stops markedly short of full-fledged embrace for U.S.-style class actions, much less related features of litigation finance"); id. at 19-37; see also Samuel Issacharoff \& Geoffrey P. Miller, Will Aggregate Litigation Come to Europe?, 62 VAND. L. REv. 179, 191-208, 209 (2009) (discussing European problems with organizational standing, litigation funding and opt-in systems, and pointing out that "[f]rom the American vantage point, we look at the European experiments with a concern that law without the institutional framework for its enforcement is necessarily lacking").

143 See Stipulation and Agreement of Settlement at 11, In re Deutsche Telekom AG Sec. Litig., 229 F. Supp. 2 d 277 (S.D.N.Y. 2002) (No. 00-CV-9475 (SHS)), available at http://securities.stanford.edu/filings-documents/1016/USD00/2005128 r04s_00CV9475.pdf; Gorga \& Halberstam, supra note 81, at 1488-91 (discussing the Deutsche Telekom case).

144 Id. at 1491 n.574.

145 Paolo Giudici, Representative Litigation in Italian Capital Markets: Italian Derivative Suits and (if Ever) Securities Class Actions, 6 Eur. Company \& FIn. L. REv. 246, 263-64 (2009).

146 See Mariana França Gouveia \& Nuno Garoupa, Class Actions in Portugal, in The Law and Economics of Class Actions in Europe 349 (Jürgen G. Bakhaus, Alberto Cassone \& Giovanni B. Ramello eds., 2012) ("The effectiveness of class action litigation in Portugal is dubious to say at least."); Deborah R. Hensler, The Future of Mass Litigation: Global Class Actions and Third-Party Litigation Funding, 79 Geo. WASH. L. Rev. 306, 309 (2010-2011) ("In most other countries with new class action regimes, there has been relatively little use of the procedure to date .... In these jurisdictions, there is a class action 
Another aspect of the problem is that Morrison's ban on foreign investor participation in U.S. class actions may also chill class actions in other jurisdictions. For example, some pre-Morrison U.S. class action counsels made use of provisions of the Dutch Class Action (Financial Settlement) Act (WCAM) statute that permitted the Amsterdam Court of Appeals to approve out-of-court settlements that parties have voluntarily negotiated, to settle nonU.S. investors' claims as happened in the Shell Petroleum case. ${ }^{147}$ However, post-Morrison, because non-U.S. investors lack class action remedies in the United States, companies may not have incentives to pursue those settlements with non-U.S. investors overseas. ${ }^{148}$ In this way, Morrison also precludes the

procedure 'on the books,' but so far little appetite for using it.”); Muir, Liu \& $\mathrm{Xu}$, supra note 115 (discussing the failures of the Chinese system); Véronique Magnier, The French Civil Litigation System, the Increasing Role of Judges, and Influences from Europe, 622 Annals Am. Acad. Pol. \& Soc. Scr. 114, 120 (2009) (identifying issues that would impair class actions in France); Rachel Mulheron, The Case for an Opt-Out Class Action for European Member States: A Legal and Empirical Analysis, 15 Colum. J. Eur. L. 409 (2008-2009) (discussing the shortcomings of the English system); Manning Gilbert Warren III, The U.S. Securities Fraud Class Actions: An Unlikely Export to the European Union, 37 BROOK. J. INT'L L. 1075, 1100-10 (2012) (surveying recent European developments, including the "Rapporteur on Towards a Coherent European Approach to Collective Redress" and pointing out their problems); Mikko Välomäki, Introducing Class Actions in Finland: An Example of Law-Making Without Economic Analysis, in The Law and Economics of Class Actions in Europe, supra, at 338 ("The Finnish implementation [of class actions] is one example of a failed process."); see also S.I. Strong, Regulatory Litigation in the European Union: Does the U.S. Class Action Have a New Analogue?, 88 Notre Dame L. Rev. 899, 969 (2012) ("European authorities need to proceed carefully, since there are signs that several of the procedures that are currently being proposed may unintentionally diminish the regulatory effectiveness of the collective redress mechanisms that are to be adopted.").

147 Warren, supra note 146, at 1093-95. It is worth noting that even the most frequently lauded system of the WCAM restricts itself to securing court approval of outof-court settlements and does not provide tools for class recovery of monetary damages. Id. at 1110; see also Hensler, supra note 146, at 318 ("WCAM is a settlement vehicle.").

148 Warren, supra note 146, at 1097:

It is reasonable to doubt whether Shell or Converium would have vigorously pursued settlements with non-U.S. investors if those investors had no class action remedies in the United States and had to deal with daunting legal obstacles in the EU member states in filing individual or collective claims. Post-Morrison, it appears unlikely that companies accused of securities fraud will be inclined to reach massive settlements with U.S. class action 
development of class action remedies in foreign jurisdictions, exacerbating the problem of wealth transfers from foreign to U.S. investors.

Still, one could raise exactly the opposite argument - that because Morrison signals that foreign investors can no longer rely on the protection of American law, foreign countries are incentivized to enact laws that protect their own investors. Accordingly, a possible solution for the double circularity problem relies not on reforming U.S. law, but on the development of foreign laws, an issue I further discuss in the next Part along with other reform proposals.

Before moving to reform considerations, final remarks are necessary to address possible critiques that object to this Article's thesis by relying on market solutions incorporating price-adjusting mechanisms.

Scholars may argue that holding an ADR is not identical to holding the underlying share traded in the company's home country. Investors hold different types of securities, negotiated under different securities regulatory regimes, and they should be familiar with the legal differences and legal risks that exist in each jurisdiction. Under this rationale, if investors are aware that they cannot rely on legal protection against securities fraud, they will discount securities prices so as to protect themselves ex ante against potential future losses. In this view, the Brazilian shareholders in the cases discussed were aware of the shortcomings in Brazilian securities litigation and accordingly adjusted the prices they paid for the companies' shares. Moreover, they also assumed the legal risk of investing in cross-listed companies, knowing that those companies could be sued according to U.S. laws and end up paying large settlements. In this sense, they voluntarily subjected themselves to the risk of the wealth transfers discussed earlier. The prices of securities trading on international markets will anticipate the costs associated with potential wealth transfers to U.S. securities holders and adjust accordingly. Following this rationale - based heavily on efficient market theory - foreign investors will be protected against wealth transfers, because they will acquire their securities at a discounted price in a well-functioning, well-informed market.

There are, however, a number of reasons why I believe price-adjusting mechanism in this particular arena would not survive a careful analysis. First, one should note that the accuracy of the market rationale hinges on the timing of a company's life cycle and its decision to cross-list, as well as the investor's own time horizon. Consider the Aracruz and Sadia cases, in which the cross-listing decision was made after many investors had already acquired securities in Brazilian market public offerings. These "first acquirers" longterm investors would not expect to lose future value due to legal risks assumed

law firms regarding claims of non-U.S. investors that can no longer be asserted in U.S. courts. 
in a foreign jurisdiction, precisely because they could not have anticipated with any certainty that the firms in which they were investing would later cross-list in the United States.

Second, if the legal-bonding hypothesis - before Morrison - justified the cross-listing premium associated with listing in the U.S. market, those investors who acquired shares after the cross-listing announcement would have paid a higher premium because they would have expected to enjoy better legal protection from investing in a U.S. cross-listed company. ${ }^{149}$ However, post-Morrison they enjoy exactly the same deficient level of legal protection of a non-cross-listed company investor. ${ }^{150}$

Third, price-adjusting arguments assume efficient capital markets. But, empirical studies that have tried to measure the efficiency of several capital

149 In other words, even if they were aware of the flaws of the Brazilian law, they counted on the U.S. laws to protect them as a result of the cross-listing, and for this reason paid more for the shares of cross-listed companies. In this situation, long-term first investors may have enjoyed the cross-listing premium afterwards, which could hypothetically work as a functional equivalent to a risk-premium for the possibility that a cross-listing could entail a wealth transfer to U.S. investors from securities litigation. Under this reasoning, in order to place a value on the wealth transfer one could try to estimate the unconditional probability that there would be loss from securities fraud, multiplied by the lost value, and compare it to an estimate of the higher valuation of the company's shares traded on the Brazilian market as a result of the cross-listing before the loss. I am grateful to Roberta Romano for pointing out this measurement possibility. However, even the supposed cross-listing risk-premium does not solve the ex post distributional problem with respect to the holders of the securities suffering from the double circularity problem. Imagine, for example, that all other things equal, two investors buy securities on different days enjoying exactly the same risk-premium for potential losses due to securities fraud and lack of compensation in their home country. Then consider that a securities fraud is afterwards revealed, showing inflation in the price paid by only the second investor. This leaves the second investor worse off than the first, because the former will actually bear the impact of the harm due to the price inflation while the latter, although enjoying a riskpremium, was not in practice affected by the inflation. The price adjusting, which both investors relied on ex ante, does not address practical ex post economic distributional and fairness effects emerging from the securities fraud.

150 It is still unclear the effect that Morrison produced on the supposed premium of cross-listed companies. See supra note 124 for studies analyzing the effects of Morrison on share price of cross-listed companies. A possible hypothesis is that Morrison will dissipate or considerably diminish the legal bonding associated with a U.S. cross listing. If the premium persists, reputational bonding, and factors other than legal bonding per se may then explain it. See supra note 105. 
markets around the world have rejected the efficiency hypothesis in the strong or semi-strong forms - which could fully account for a discount in the price due to a perception of future distributional losses. ${ }^{151}$ Therefore there is large support for the view that markets do not operate flawlessly — otherwise why would we need securities regulation at all? As long as one acknowledges there are market failures and externalities effects, there is room for regulation aiming to correct or at least diminish those problems.

Fourth, the same market-based objections to the double circularity problem could be similarly raised with respect to the circularity problem. Why isn't all securities litigation abolished on the grounds that securities frauds are resolved by the ex-ante market pricing mechanism? We could envision a no-law world in which all investors discount for all fraud possibilities, with no regulation or litigation to protect investments and provide recovery for fraud-related losses. Allegedly by discounting the price of securities ex ante, U.S. investors, as foreign investors, would also be perfectly protected. Nonetheless, this is not the world in which we now live. ${ }^{152}$

Fifth, general price discounting may ultimately result in securities prices so low for all issuers that investors will not be able to distinguish good companies from bad. This could lead to a market-for-lemons problem ${ }^{153}$ and ultimately lock the market into a low level equilibrium that is not conducive to economic development. Reputational issuers may be driven out of capital markets to look for alternative sources of finance.

Therefore, a case can be made that transnational wealth transfer problems are unlikely to be dissipated by pure market functioning. In this sense, this

151 See, e.g., Sanford J. Grossman \& Joseph E. Stiglitz, On the Impossibility of Informationally Efficient Markets, 70 Am. Econ. Rev. 393 (1980); Barr Rosenberg, Kenneth Reid \& Ronald Lanstein, Persuasive Evidence of Market Inefficiency, 11 J. Portfolio Mgmt. 3, 9 (1985); Meredith Beechey, David William Gruen \& James Vickery, The Efficient Market Hypothesis: A Survey (Reserve Bank of Australia, Research Discussion Paper, 2000), available at http://www.rba.gov. au/publications/rdp/2000/pdf/rdp2000-01.pdf; see also Érica GorGA, Direito Societário Atual [Contemporary Corporate Law] 83-85 (2013) (reviewing studies on the efficiency of Brazilian capital markets and showing that most of them display efficiency in the weak form or lack efficiency). Strong, semi-strong and weak are forms of market efficiency. See Eugene Fama, Efficient Capital Markets: A Review of Theory and Empirical Work, 25 J. FIN. 383 (1970).

152 Further, if we learned anything from the 2008 financial crisis and the others that came before it, it is that leaving the markets free to operate by themselves will not necessarily produce the best world for investors.

153 George A. Akerlof, The Market for "Lemons:" Quality Uncertainty and the Market Mechanism, 84 Q.J. EcoN. 488 (1970). 
Article questions whether the current national regulatory and enforcement systems based on contrasting legal responses for holders of similar securities - with equivalent economic rights - who suffered from the same factual wrongdoing make sense for a transnational securities market increasingly globalized and interdependent. In this context, the next Part discusses regulatory proposals to fix such distributional imbalances.

\section{ReForm Considerations}

Morrison's geographic transactional test was also motivated by the Supreme Court's intention to diminish political tensions with other countries. ${ }^{154}$ Yet this Article shows that this test has resulted in severe economic tensions among investors of the same issuer, raising serious concerns about international economic fairness. The integration of transnational securities markets requires coping not only with political conflicts of legal jurisdiction, but also with problems of wealth distribution among similar investors of the same issuer. While this Article does not attempt to develop a broad new regulatory proposal, this Part reviews reform proposals advanced by the literature with the purpose of determining which might solve the problem of wealth transfers from foreign to U.S. investors.

\section{A. U.S.-Based Reforms}

Some of the current reform recommendations would in fact worsen economic tensions. For instance, if the U.S. Congress maintained Morrison's ban on f-cubed litigation and expanded antifraud claims against foreign issuers for American investors acquiring securities in other jurisdictions (f-squared complaints), as some current proposals contemplate, ${ }^{155}$ wealth transfer effects between American investors and foreign investors would tend to increase. In addition to the transactional criterion determined by Morrison, this proposal would introduce a nationality bias that would further aggravate the imbalance. This Article therefore cautions against the adoption of such proposals.

The distributional problems created by the exceptional nature of the U.S. regulatory framework can only be solved by providing equal regulatory

154 See Morrison v. Nat'l Austl. Bank Ltd., 130 S. Ct. 2869, 2885-86 (2010) (referring to the amicus curiae briefs of the United Kingdom, Australia and France and stating that the rule adopted by the Court meets other countries' concerns that the reach of the antifraud provisions can interfere with their own regimes of securities regulation); Fox, supra note 80, at 1271.

155 See supra notes 111-112, 114-115 and accompanying text. 
treatment for U.S. and foreign investors. Theoretically, this could be achieved by uniformity in the U.S. regulatory approach, either in a negative (abstention) or positive (extensive) way. The negative approach would mean that the United States abstains from applying its securities regulation to foreign issuers in all possible complaints - including the claims brought by American investors who acquired cross-listed securities on the U.S. stock exchanges and markets. This proposal has been endorsed by scholars such as Fox. ${ }^{156}$ The positive approach would mean that the United States extends the securities laws protection that its domestic investors enjoy to foreign investors as well. ${ }^{157}$

Both theoretical possibilities would require overturning Morrison. The negative approach would implicitly transfer jurisdiction of securities laws rights relative to U.S. investors acquiring securities from foreign companies to their foreign home countries. The positive approach, in contrast, would extend the extraterritorial effects of U.S. securities laws to foreign investors and include a complete acceptance of f-cubed claims in the United States. But this approach would also require changing the type of pre-Morrison inquiries based on the conduct and effects tests, ${ }^{158}$ as well as prerequisites for class certification, ${ }^{159}$ as maintaining these tests and restrictions could lead to the double circularity problem explained above whenever foreign investors have their claims dismissed for lack of subject-matter jurisdiction (either by conduct or effect) or of superiority requirement. ${ }^{160}$

156 Fox, supra note 80 , at 1205, 1272-73. Fox analyzes policy justifications for U.S. fraud on the market claims, but concludes that such claims "should not be imposed on genuinely foreign issuers, even if the claimants are U.S. residents or have effected their purchases on U.S. markets.” Id. at 1205. Fox's proposal is appealing in the sense that it attacks the distributional problem at its roots. If buyers who engaged in transactions in the U.S. markets lack a cause of action to file claims against foreign issuers, the wealth transfers discussed above are precluded. He admits, however, an exception to this general rule when a foreign issuer voluntarily abides by the U.S. liability regime, a reform possibility that I address below.

157 The SEC proposal discussed supra note 125 and accompanying text supports this view.

158 See supra notes $89,90-91$ and accompanying text.

159 See supra notes 87-88 and uccompanying text.

160 These reforms would also rely to some extent on the consent of foreign jurisdictions in enforcing class action decisions and settlements against foreign corporations, which would trigger the recognition problems discussed supra notes 87-88 and accompanying text. See also Mulheron, supra note 146, at 445-46 (discussing the non-recognition risk factor). 


\section{B. Foreign-Based Reforms}

Another distinct alternative is to rely instead on the future development of securities antifraud litigation in international jurisdictions to fix present imbalances. Peta Spender and Michael Tarlowski have suggested that Morrison will produce a "centrifugal effect" on transnational securities litigation. ${ }^{161}$ In this view, securities class actions would flow to other jurisdictions that adopted "opt out procedures" such as those used in Australia. Nevertheless, many potential barriers to this alternative exist. Most countries currently lack the legal mechanisms and economic incentives that make possible effective capital markets aggregate litigation. ${ }^{162}$ As an example, Spender and Tarlowski themselves point out that Australia's legal environment lacks contingency fees and types of punitive damages, and uses the loser-pays rule. ${ }^{163} \mathrm{I}$ believe these very characteristics may not be conducive to the filing of class actions.

If, according to this view, Morrison could catalyze regulatory reform in other countries ${ }^{164}$ one might have expected that the Sadia and Aracruz cases would have exerted competitive pressure on Brazilian regulators to maximize the welfare of Brazilian investors, and to pass legislation that would protect their interests, allowing new enforcement actions that enable direct financial recovery. Nonetheless, nothing has developed in this direction in Brazil so far. ${ }^{165}$ Hence, this laissez-faire approach is unlikely to cure current flaws, especially in consideration of the fact that path dependency usually impairs significant legal changes. ${ }^{166}$

Hannah Buxbaum has discussed whether foreign investors could find a route to recovery in the United States independent of the application of U.S.

161 Peta Spender \& Michael Tarlowski, Morrison v. National Australia Bank Ltd. Adventures on the Barbary Coast: Morrison and Enforcement in a Globalised Securities Market, 35 Melbourne. U. L. Rev. 280, 314 (2011).

162 See supra note 146.

163 Spender \& Tarlowski, supra note 161, at 314.

164 See Genevieve Beyea, Morrison v. National Australia Bank and the Future of Extraterritorial Application of the U.S. Securities Laws, 72 Оніо Sт. L.J. 537, 570 (2011) (further arguing that Morrison has the potential to encourage greater international cooperation to cope with transnational securities fraud); see also Choi \& Silberman, supra note 25, at 501.

165 See generally Érica Gorga, Culture and Corporate Law Reform: A Case Study of Brazil, 27 U. PA. J. INT'L EcON. L. 803 (2006) (discussing problems for law reforms in Brazilian capital markets).

166 See generally Lucian A. Bebchuk \& Mark J. Roe, A Theory of Path Dependence in Corporate Ownership and Governance, 52 STAN. L. REv. 127 (1999). 
securities laws. ${ }^{167}$ One possibility would be to rely on claims arising under foreign securities law. However, procedural obstacles such as establishing subject matter jurisdiction, avoiding dismissal based on forum non conveniens, and meeting class certification provide multiple bases on which a U.S. court could decline jurisdiction. ${ }^{168}$ This alternative depends on the judgment of U.S. courts, which tend to be reluctant to apply foreign securities law. ${ }^{169}$ This reluctance aside, even if foreign investors could rely on U.S. courts to apply foreign securities law to solve antifraud cases, such application may be insufficient, precisely because of the laxer legal standards for investor protection in many other countries. ${ }^{170} \mathrm{As}$ a practical matter, foreign investors are unlikely to obtain financial recovery in the United States under foreign securities law claims that could minimize the wealth transfers to U.S. investors that they currently bear.

\section{Private Ordering Reforms Based on Issuer and Investor Choices}

Other set of regulatory reforms seem to enable all investors of the same corporation who were subjected to losses caused by the same wrongdoing to obtain the same litigation outcome - and the same financial recovery, if any.

Roberta Romano has proposed that issuers and investors choose their regulatory regimes independent of firm or investor residence and the location of the securities transaction. Such an approach "reduces the possibility that a regulator will be able to transfer wealth across different regulated entities or redistribute wealth from the regulated sector to preferred individuals

167 Buxbaum, supra note 100, at 173.

$168 \mathrm{Id}$. at $175-78$. Buxbaum also explores the possibility of relying on recovery through mechanisms of public enforcement, which "may be more capable than private enforcement of successful integration into the overall scheme of international securities regulation." Yet, she points out that the SEC may have a policy restriction on which cases to pursue. $I d$. at 185. Empirical research has indeed shown that the enforcement actions against foreign issuers by the SEC are very limited when compared to domestic issuers. See Shnitser, supra note 105; Siegel, supra note 105.

169 Buxbaum, supra note 100, at 183 ("[T] he prospects for asserting claims arising out of foreign transactions on the basis of foreign governing law seem slim.").

170 See supra notes 142-148 and accompanying text. See generally Simeon Djankov, Rafael La Porta, Florencio Lopes-de-Silanes \& Andrei Shleifer, The Law and Economics of Self-Dealing, 88 J. Fin. Econ. 430, 461 (2008) (finding that common law countries outperform civil law countries in an index of shareholder protection against self-dealing transactions in seventy-two countries, which implicitly suggests U.S. superiority). 
or organizations." securities regime governing their transactions and that investors approve any regime changes. In addition, local judiciaries would have to recognize forum selection for the resolution of private securities lawsuits - including arbitration. Alternatively, exchanges could demand as a listing requirement the disclosure of domicile and, therefore, of litigation forum. ${ }^{172}$ By making the choice of law applicable to all securities holders, Romano's "issuer choice" proposal avoids distributional problems, since all securities holders would receive equal treatment, whether or not they qualify for an indemnification.

Wolf-Georg Ringe and Alexander Hellgardt have proposed bundling securities liability and disclosure duties under the same applicable law for all issuers, regardless of the precise market place of the transaction or the nationality or residence of a harmed investor. They defend the use of the lex incorporationis, under which an investor can reliably learn which rules apply to an issuer. ${ }^{173}$ Liability of cross-listed firms should also be governed by a disclosure regime, and when an issuer is voluntarily subject to more than one disclosure regime, harmed investors may choose the liability rules, independent of their nationality or place of securities acquisition. According to this rationale, all investors will be able to enjoy stricter liability rules from the cross-listing jurisdiction, and therefore should be allowed to sue for damages under U.S. law. ${ }^{174}$ This proposal provides the choice of law to investors, and therefore may solve the wealth transfer problem if investors are able to choose jurisdictions that better protect their interests.

Therefore if issuers could voluntarily subject themselves to one particular antifraud regime to regulate their transactions in all jurisdictions in which they list their securities, ${ }^{175}$ investors would receive the same legal response to the

171 Roberta Romano, The Need for Competition in International Securities Regulation, 2 Theoretical Inquiries L. 1, 6-7 (2001).

172 Id. at 15.

173 Wolf-Georg Ringe \& Alexander Hellgardt, The International Dimension of Issuer Liability - Liability and Choice of Law from a Transatlantic Perspective, 31 Oxford J. Legal Stud. 23, 50-51 (2011); id. at 56 ("Those issuers that most adhere to U.S. disclosure duties should consequently be liable under U.S. fraud rules when they violate those duties, no matter where a transaction takes place or a certain investor is located.").

174 Id. at 56-57.

175 Fox, supra note 80, at 1213 (putting forward a proposal along the same lines in the U.S. domestic market, and arguing that "foreign issuers that choose to be subject to U.S. fraud-on-the-market class actions will be liable to all purchasers, wherever resident and wherever they purchased their shares, to the same extent that a U.S. issuer would be in an entirely domestic context"). 
same complaints independent of the place of the transaction. Along the same lines, involuntary transfers of capital would be precluded if investors were allowed to choose the litigation venue in which they bring their claims. While I do not attempt to address the challenges of implementation, such policies would guarantee that securities holders of the same issuers receive a pro rata distribution of corporate compensation in the case of shareholder recovery, thus assuring fairness and an efficient distribution of corporate resources. ${ }^{176}$

Having analyzed a variety of proposals, this Article endorses those that provide for a system of adjudication of transnational securities litigation producing equal treatment for securities holders subject to the same wrongdoing regardless of the nationality of the purchasers or the location of purchase/ sale. This result would be best achieved through issuer or investor choice of applicable legal regime. These approaches would ensure that investors who acquired similar securities face company-specific risks instead of pure legal risks, diminishing the ability of companies to engage in legal arbitrage at the expense of a specific group of security holders. Another advantage of this proposal is that it enables economies of scale at the international level, ${ }^{177}$ as a transnational regime of adjudication would save on the costs associated with differing applicable legal regimes and litigation in multiple forums.

While I do not attempt here to provide all details of implementation, some possible strategies could include a supranational securities regulator with jurisdiction to adjudicate transnational securities litigation and guarantee uniform treatment of investors who hold securities of the same companies. One could also think of private ordering solutions by which corporations could choose to solve all their legal disputes in particular jurisdictions or subject themselves to arbitration clauses that provide equivalent legal remedies to equivalent securities holders. States, accordingly, would have to cede their jurisdiction to legitimize such arrangements. Corporate governance codes of best practices and stock exchange listing rules could also promote or require that all investors be treated equally in transnational securities litigation so as to avoid the double circularity problem.

\section{Conclusion}

This Article has analyzed private enforcement actions brought against Brazilian corporations in the United States and in Brazil for the same kind of corporate misconduct. This scenario allows an unprecedented comparative inquiry

$176 \mathrm{Id}$. at 1217.

$177 \mathrm{Id}$. at 1220 . 
into legal approaches to securities frauds and their legal outcomes in these two different jurisdictions. While U.S. investors were able to directly obtain financial recovery in class action settlements, Brazilian investors lacked the legal mechanisms necessary for seeking direct compensation. Additionally, Brazilian investors bore the costs of the compensation paid to U.S. investors. The small cash recovery produced by the Brazilian derivative suit in the Aracruz case resulted in indirect benefits to both Brazilian and U.S. investors.

My analysis therefore reveals wealth transfers from foreign to U.S. investors in the current system of transnational securities litigation, which are effected by contrasting private enforcement mechanisms producing different outcomes. The Article also argues that the Morrison decision has aggravated such distributional problems, and sheds light on the costs Morrison has imposed on foreign investors. As foreign jurisdictions tend to be significantly less protective of investor interests than the United States - as demonstrated by the Sadia and Aracruz cases - U.S. investors tend to receive non pro rata compensation despite holding similar economic rights to those of foreign investors. Moreover, foreign investors also support the costs associated with such U.S. investors' recoveries. The Article has identified a "double circularity problem," so far neglected by policymakers and scholarship, which stems from the fact that the very foreign shareholders who were harmed by the securities fraud may also bear the costs of the recoveries achieved by U.S. investors. This problem therefore casts serious doubt on the welfare of the current system of international securities litigation, producing allocation and fairness problems in globalized securities markets.

Having revealed such a flaw in the current system, the Article then surveyed existing reform proposals for fixing transnational securities litigation. Some reform proposals aggravate or ignore this problem, while others mitigate it. The Article endorsed proposals that allow the implementation of a uniform system for the adjudication of transnational securities litigation for all securities holders of the same company. Systems of issuer or investor choice would better promote an efficient allocation of remedies as well as legal and economic fairness in international markets.

The Article has also discussed other possible solutions based on U.S. or foreign jurisdictions reforms. A U.S. solution would require overturning Morrison. In addition, it would demand either the abstention of U.S. securities law jurisdiction from U.S. acquirers of securities of foreign issuers or an extension of extraterritorial effects of U.S. securities law to all foreign investors. In contrast, foreign solutions would require reforms that create and implement the legal infrastructure necessary to provide direct recovery mechanisms to foreign investors groups so as to protect them against losses due to securities fraud. The practical limitations of these approaches were acknowledged. 
Fixing the problem with transnational securities litigation will improve international corporate governance. It will avoid a scenario in which only a portion of investors support the costs of corporate governance failures and instead provide that securities holders obtain equivalent loss remedies. A broad range of solutions can be envisioned, including a supranational securities regulator, stock exchange listing requirements, choice of litigation forum, and arbitration clauses that enable the adjudication of transnational securities lawsuits in a coherent way to all harmed securities holders. Corporate governance codes of best practices could also push for equalitarian treatment of investors in transnational securities litigation so as to prevent the double circularity problem. 
Brought to you by | Universitaetsbibliothek Basel

Authenticated

Download Date | 4/29/19 4:08 PM 